Report No. BMI- 1261

UC-25 Metallurgy and Ceramics (TID-4500, 13th Ed., Rev.)

Contract No. W-7405-eng-92

THE COMPATIBILITY OF A NUMBER OF METALS

AND ALLOYS WITH GRAPHITE

by

Arnold F. Gerds

Manley W. Mallett

\author{
April 14, 1958 \\ BATTELLE MEMORIAL INSTITUTE \\ 505 King Avenue \\ Columbus 1, Ohio
}




\section{DISCLAIMER}

This report was prepared as an account of work sponsored by an agency of the United States Government. Neither the United States Government nor any agency Thereof, nor any of their employees, makes any warranty, express or implied, or assumes any legal liability or responsibility for the accuracy, completeness, or usefulness of any information, apparatus, product, or process disclosed, or represents that its use would not infringe privately owned rights. Reference herein to any specific commercial product, process, or service by trade name, trademark, manufacturer, or otherwise does not necessarily constitute or imply its endorsement, recommendation, or favoring by the United States Government or any agency thereof. The views and opinions of authors expressed herein do not necessarily state or reflect those of the United States Government or any agency thereof. 


\section{DISCLAIMER}

Portions of this document may be illegible in electronic image products. Images are produced from the best available original document. 


\section{TABLE OF CONTENTS}

Page

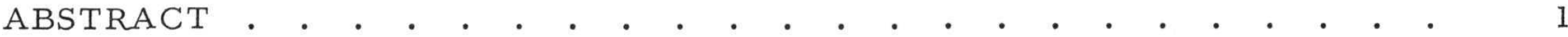

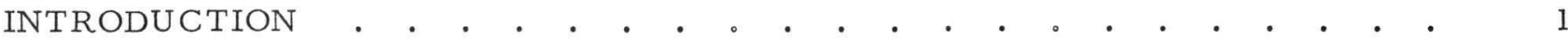

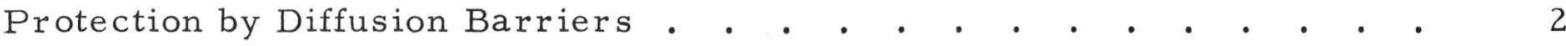

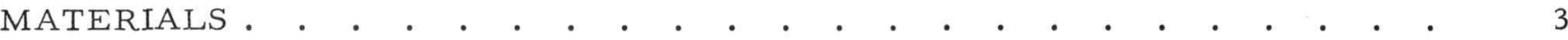

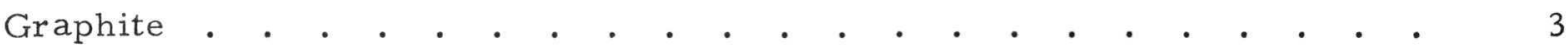

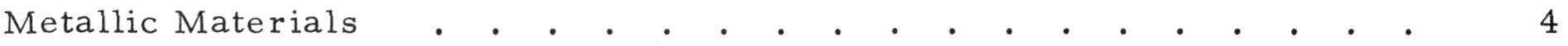

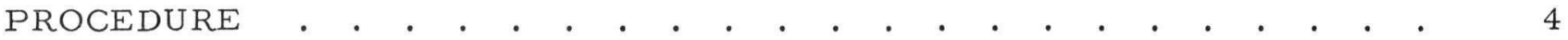

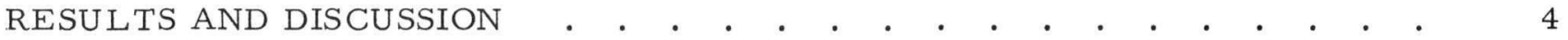

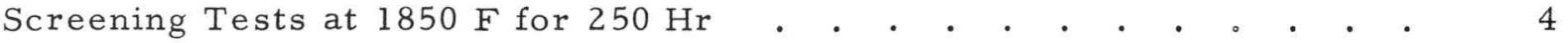

Unalloyed Metals • • • • • • • • • • • • • • • . . 44

Nickel-Base Alloys • • • • • . • • • • • . . . . . 66

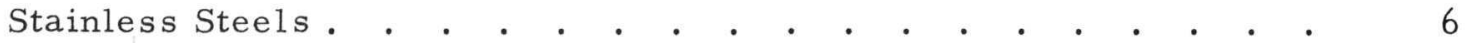

Plated Type 316 Stainless Steel . . . . . . . . . . . . 66

Tests at $1650 \mathrm{~F}$ for $1000 \mathrm{Hr}$. . . . . . . . . . . . . . 。 12

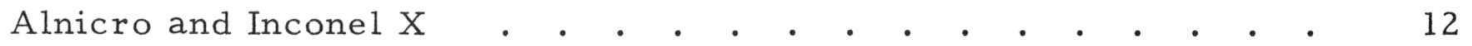

Type 316 Stainless Steel . • • . • . • . . . . . . . 16

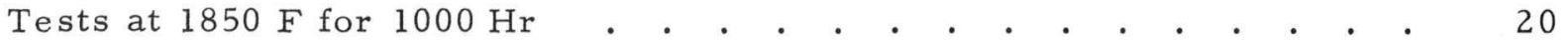

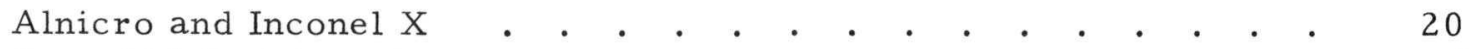

Type 316 Stainless Steel . . . • . . . . . . . . . . 24

CONCLUSIONS • • • • • • • • • • • • • •

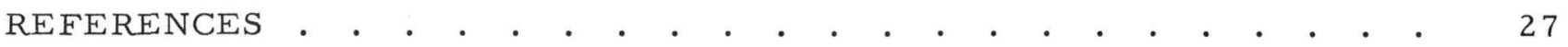




\title{
THE COMPATIBILITY OF A NUMBER OF METALS AND ALLOYS WITH GRAPHITE
}

\author{
Arnold F. Gerds and Manley W. Mallett
}

\begin{abstract}
The interaction between graphite and a number of metals and alloys was studied at $1850 \mathrm{~F}$ in 250-hr tests. Some materials were also tested at 1650 and $1850 \mathrm{~F}$ in 1000-hr tests. The graphite was heated in intimate contact with the test metal in welded metallic capsules. The extent of the reaction was judged on the basis of metallographic examinations and hardness traverses on cross sections of the reacted elements.
\end{abstract}

Copper was the least reactive material tested in contact with graphite. Nickel was only slightly more reactive. Outside of a very hard carbide band at the graphite-metal interface, no evidence of interaction of carbon with molybdenum was found.

Inconel $X$ was the most compatible alloy tested in contact with graphite, although some pickup was observed. Alnicro was the next best alloy. Nichrome V, Inconel, and Types 316 and 318 stainless steels were all much more reactive. Copper and chromium plating reduced the rate of diffusion of carbon into Type 316 stainless steel. Nickel plating was less effective for this purpose.

\section{INTRODUCTION}

The temperature of a reactor using graphite in contact with metal may be limited by a reaction between the graphite and the metal. Diffusion of carbon may result in deterioration of the desired properties of the metal. This report gives the results of a study of the compatibility of a number of metals and alloys with graphite on the basis of 250- and 1000-hr tests at $1850 \mathrm{~F}$. Results of a 1000-hr test with several of the materials at $1650 \mathrm{~F}$ also are included.

The metals and alloys tested were chosen for this study on the basis of their physical properties, mechanical properties, and economic considerations. Only some of the materials may not be compatible with graphite. Others may be resistant to carburization but may be borderline in respect to other properties. Composites of these two types of materials in the form of one plated on the other may produce a useful material. The available phase diagrams and other literature references were examined, and gave the following information on a number of possible metals and alloys that might be considered:

Molybdenum-Carbon (1). The melting point of molybdenum is $4790 \mathrm{~F}$. Molybdenum dissolves about $0.1 \mathrm{w} / 0$ carbon at 3600 to $3800 \mathrm{~F}$ (two carbides, $\mathrm{Mo}_{2} \mathrm{C}$ and $\mathrm{MoC}$, are reported). The carbide can be formed(2) by reaction of molybdenum powder or molybdenum oxide with carbon black at 2200 to $2900 \mathrm{~F}$.

(1) References at end. 
Nickel-Carbon(1). The melting point of nickel is $2651 \mathrm{~F}$. At the eutectic temperature, $2400 \mathrm{~F}$, the solid solubility of carbon in nickel is $0.65 \mathrm{w} / \mathrm{o}$. This decreases to about $0.25 \mathrm{w} / \mathrm{o}$ at $1750 \mathrm{~F}$. No stable carbides are reported for this system.

Copper-Carbon ${ }^{(1)}$. Copper forms no stable carbides. The solid solubility of carbon in copper is very low (about $0.0001 \mathrm{w} / \mathrm{o}$ ). However, copper melts at $1981 \mathrm{~F}$ and this may limit its usefulness as a structural material at high temperatures.

Chromium-Carbon(1). The melting point of chromium is $3430 \mathrm{~F}$. Chromium is a carbide former, the system showing three stable carbides. The solubility of carbon in chromium is less than $0.1 \mathrm{w} / \mathrm{o}$. The carbide is reported (2) to form by reaction with lamp black at 2550 to $3270 \mathrm{~F}$.

Stainless Steel-Carbon(1). Since iron is the base for the stainless steels, its properties are of interest. The melting point of iron is $2802 \mathrm{~F}$. The iron-carbon system contains the stable carbide $\mathrm{Fe}_{3} \mathrm{C}$. Only 0.025 w/o carbon is soluble in the low-temperature ferrite at the eutectoid temperature $(1360 \mathrm{~F})$. However, $1.7 \mathrm{w} / \mathrm{o}$ carbon is soluble in austenite at the eutectic temperature $(2075 \mathrm{~F})$. At $1750 \mathrm{~F}$, the solubility of graphite in austenite is about $1.3 \mathrm{w} / \mathrm{o}$.

Stainless steels are essentially iron-chromium-nickel alloys. The addition of chromium and nickel to iron decreases the solubility of graphite in austenite from about $1.3 \mathrm{w} / \mathrm{o}$ to about $0.1 \mathrm{w} / \mathrm{o}$ at $1750 \mathrm{~F} .{ }^{(3)}$ Thus, any carbon in excess of this amount would be present as a carbide.

Only a few references were found in the literature on the carburization of stainless steels. On the basis of a limited number of 200-hr tests at $1382 \mathrm{~F}$ $(750 \mathrm{C})$, the stabilized stainless steels, Types 321 and 347 , were reported(4) to be more resistant to carburization than Type 316 and much more resistant than Type 310, both of which are unstabilized. One-hour exposures at $1900 \mathrm{~F}$ of a number of stainless steels to carburizing compounds in vacuum indicated(5) that Type 347 stainless steel absorbed less carbon than Types 304 or 316 . A surface oxide on the stainless steel was reported(5) to retard the carbon absorption. The penetration of carbon into stainless steel at $1382 \mathrm{~F}$ also was reported $(4)$ to be greatly retarded by copper plating the steel.

\section{Protection by Diffusion Barriers}

As indicated above, certain metals and alloys appear to have satisfactory physical properties at temperatures up to $1850 \mathrm{~F}$. It is to be expected that at least some of these will deteriorate from carbon pickup, and therefore some consideration of protective barriers is appropriate. Unless such barriers have absolutely no solubility for carbon, they cannot prevent the base metal from eventually becoming saturated with respect to carbon - they can only postpone the time at which saturation is reached. 
Two types of barriers should be considered: (1) the carbide layer naturally formed on some metals during reaction, and (2) layers of a third material deliberately interposed between graphite and the metal. A carbide layer on the base metal cannot retard pickup of carbon from the carbide layer to the metal. However, reaction to form more carbide will be impeded if the carbide layer is coherent, for in that case the reaction would be diffusion controlled. Carbides which crack or powder during formation would not constitute a barrier.

Interposition of a barrier material between a metal and a surrounding medium is, of course, the common technique used to prevent corrosion at moderate temperatures. The technique should be applicable for protection of metals at more elevated temperatures. While barriers produced by electrodeposition are subject to discontinuities that may, in some cases, reduce their effectiveness, those produced by other techniques such as hot dipping, pressure bonding, etc. are not subject to this limitation.

The rate of transfer (permeation) of material across a thin nonporous barrier layer by diffusion is proportional to the diffusion constant and the concentration gradient, and inversely proportional to the thickness. For the case of protection provided by a layer of a third material of constant thickness, steady-state conditions can be assumed. Materials with a very low solubility would be desired because the maximum concentration gradient for a given thickness would be correspondingly small. A small diffusion coefficient and a thick layer would also be desirable.

Carbide layers may also be produced at the graphite-barrier interface where they would, of course, grow in thickness as the reaction proceeded. This growth would slow the over-all reaction but would not retard the diffusion of carbon through the barrier. Carbide layers forming at the barrier-metal interface would tend to destroy the barrier-metal bond and probably distort the assembly.

The most successful protective barriers will probably be those of metals having a low permeability rate for carbon. Again, this implies a low diffusion coefficient and/or a low carbon solubility.

\section{MATERIALS}

\section{Graphite}

The graphite used in these tests was prepared by hot mixing Texas coke with standard pitch. The mixture was pressed at $120 \mathrm{~F}$ in a molding die at $12,000 \mathrm{psi}$ into a bar 1 in. thick by $4-1 / 2$ by 2 in. The compact was heated very slowly to $2500 \mathrm{~F}$ in 7 days in a gas-fired furnace to permit the volatile constituents to be evolved, and then baked at $2500 \mathrm{~F}$ for $4 \mathrm{hr}$. Following this, the material was graphitized at $4500 \mathrm{~F}$ for $4 \mathrm{hr}$.

The pitch-bonded compacts had a baked density of $1.50 \mathrm{~g}$ per $\mathrm{cm}^{3}$ and a density of of $1.47 \mathrm{~g}$ per $\mathrm{cm}^{3}$ in the graphitized condition. 
Metallic Materials

The metals and alloys heated in contact with graphite were commercially available materials. Their nominal compositions are listed in Table 1.

\section{PROCEDURE}

Sandwich-type elements were used for this study. These comprised cups of Type 303 stainless steel containing disks of the test metal and graphite in intimate contact with each other. The cups were $3 / 4 \mathrm{in}$. high, $1 / 2 \mathrm{in.}$ in OD, and contained cavities $1 / 4 \mathrm{in}$. in diameter and $1 / 2 \mathrm{in}$. deep. The test metals were machined into disks $1 / 4 \mathrm{in}$. in diameter and up to 50 mils thick. Those made from sheet stock were the thickness of the sheet. A disk to be tested was inserted into a cup. A graphite cylinder, 1/4 in. in diameter and 1/4 in. high, was placed on the disk and a second metal disk was placed on top of the graphite. A stainless steel cap then was pressed into the open end of the cup and welded tight in an argon-filled dry box.

After the excess weld metal was removed, the elements were loaded in a graphite die containing three drilled holes. For the 1000-hr runs, the outside surfaces of the stainless steel elements were plated with a l-mil thickness of copper to retard diffusion of carbon from the graphite restraining die into the elements. Elements for the 250-hr runs were not plated. Two elements, separated by a 1/2-in. -long graphite spacer, were placed in each hole of the die. Thus, six elements were heated in one experiment. A dead load of 2000 to 3000 psi was transmitted to the elements from a lever-arm device by means of graphite plungers. A Mullite furnace tube contained the dies in a protective atmosphere of argon gas. Globar-resistance furnaces supplied the heat. Temperature was regulated with a recording controller.

Preliminary screening tests were made at $1850 \mathrm{~F}$ for $250 \mathrm{hr}$. The most compatible materials then were tested for $1000 \mathrm{hr}$ at $1650 \mathrm{~F}$ and also at $1850 \mathrm{~F}$. At the end of a run the dead load was removed and the die containing the test elements was quenched in cold water.

Results of the tests were evaluated by means of metallographic examinations and hardness tests of longitudinal sections through the reaction zones.

\section{RESULTS AND DISCUSSION}

\section{Screening Tests at $1850 \mathrm{~F}$ for $250 \mathrm{Hr}$}

\section{Unalloyed Metals}

The compatibility of a number of commercially pure metals with graphite was determined by $250-\mathrm{hr}$ screening tests at $1850 \mathrm{~F}$. These metals included copper, 
TABLE 1. NOMINAL COMPOSITIONS OF METALLIC MATERIALS TESTED IN CONTACT WITH GRAPHITE

\begin{tabular}{|c|c|c|c|c|c|c|c|c|c|}
\hline \multirow[b]{2}{*}{ Material } & \multicolumn{9}{|c|}{ Composition, w/o } \\
\hline & $\mathrm{Cu}$ & $\mathrm{Ni}$ & $\mathrm{Cr}$ & $\mathrm{Fe}$ & $\mathrm{C}$ & Mo & $\mathrm{Mn}$ & $\mathrm{Si}$ & Other \\
\hline Molybdenum & -- & -- & - & 0.01 & 0.005 & $99.95(a)$ & - & -- & Oxygen -0.002 \\
\hline Copper & $99.92(a)$ & -- & -- & -- & -- & -- & -- & -- & $\begin{array}{l}\text { Phosphorus }-0.015 \text { to } 0.04 \\
\text { Oxygen }-0.04\end{array}$ \\
\hline Nickel & 0.10 & $99.4^{(a)}$ & -- & 0.15 & 0.05 & -- & 0.25 & 0.05 & Sulfur -0.005 \\
\hline Nichrome V & -- & 80 & 20 & -- & -- & -- & -- & -- & \\
\hline Inconel & 0.2 & 76 & 15.5 & 7.5 & 0.08 & -- & 0.25 & 0.25 & Sulfur -0.007 \\
\hline Inconel $\mathrm{X}$ & 0.05 & 73 & 15 & 7.0 & 0.04 & -- & 0.50 & 0.40 & $\begin{array}{l}\text { Sulfur }-0.007 \\
\text { Aluminum }-0.7 \\
\text { Titanium }-2.5 \\
\text { Niobium }-1.0\end{array}$ \\
\hline Alnicro & -- & 76 & 20 & -- & -- & -- & -- & -- & Aluminum -4.0 \\
\hline $\begin{array}{l}\text { Type } 316 \text { stainlèss } \\
\text { steel }\end{array}$ & -- & $10-14$ & $16-18$ & Balance & $0.10^{(b)}$ & $2-3$ & $2.0^{(b)}$ & $1.0(b)$ & $\begin{array}{l}\text { Sulfur }-0.03(\mathrm{~b}) \\
\text { Phosphorus }-0.04(\mathrm{~b})\end{array}$ \\
\hline $\begin{array}{l}\text { Type } 318 \text { stainless } \\
\text { steel }\end{array}$ & -- & $13-15$ & $17-19$ & Ditto & $0.08^{(b)}$ & $2.0-2.75$ & $2.5^{(b)}$ & $1.0(b)$ & $\begin{array}{l}\text { Sulfur }-0.03(\mathrm{~b}) \\
\text { Phosphorus }-0.04(\mathrm{~b}) \\
\text { Niobium }(\mathrm{c})\end{array}$ \\
\hline
\end{tabular}

(a) Minimum.

(b) Maximum.

(c) Niobium $=10 \mathrm{x}$ carbon content. 
molybdenum, and nickel. The tops of the photomicrographs in Figure 1 show at $100 \mathrm{X}$ the microstructures at the interfaces in longitudinal sections after reaction. Molybdenum formed a very hard phase (about 1400 Knoop) adjacent to the graphite. This appears as the light-etching band in the photomicrograph and is evidence of the molybdenum-carbide phases. No evidence of penetration of carbon beyond this band is shown in the photomicrograph or in the hardness-traverse results in Table 2 . The copper appears to have reacted only very slightly if at all on the basis of the photomicrograph and the hardness traverses. The slightly darkened metallic phase adjacent to the graphite may be evidence of worked metal. No evidence of reaction between nickel and graphite was noted except for a very thin layer of bright and apparently hard material at the interface. However, Table 2 shows roughly a 50 -point increase in hardness in the nickel near the interface which may be evidence of carbon dissolved to the solubility limit, $0.25 \mathrm{w} / \mathrm{o}$.

\section{Nickel-Base Alloys}

Four nickel-base alloys, Nichrome V, Alnicro, Inconel, and Inconel X were tested in contact with graphite at $1850 \mathrm{~F}$ for $250 \mathrm{hr}$. Photomicrographs of the reaction interfaces between graphite and the four alloys are shown at 100X in Figure 2. Carbon appears to have penetrated to an appreciable extent into all of these alloys on the basis of the photomicrographs and the hardness traverses in Table 2. The greatest penetration was in the Nichrome $\mathrm{V}$ and the least in the Inconel X. Of the other two alloys, Inconel was penetrated more deeply than Alnicro.

For comparison, the microstructures of the se alloys, heated at $1850 \mathrm{~F}$ for $24 \mathrm{hr}$ in the absence of graphite, are shown in Figure 3. The hardnesses of these samples are shown in the last column of Table 2. Alnicro shows the largest amount of grainboundary precipitate. The Inconel $X$ sample shows a lesser amount, while none appears in the microstructure of the Nichrome $\mathrm{V}$ and the Inconel.

\section{Stainless Steels}

The microstructures at $100 \mathrm{X}$ of Types 316 and 318 stainless steel after heating at $1850 \mathrm{~F}$ for $250 \mathrm{hr}$ are shown in Figure 4. The microstructures of the se steels heated for $24 \mathrm{hr}$ at $1850 \mathrm{~F}$ in the absence of graphite are shown for comparison. Both materials contain a thin reaction layer adjacent to the graphite and much evidence of inward diffusion of carbon beyond this layer. Although the amount of gray carbide precipitate decreases slightly with increasing distance from the interface, almost complete saturation of the specimens with carbon is evident. Results of hardness traverses, shown in Table 2, appear to verify this observation. No evidence of precipitated carbides is seen in the samples heated at $1850 \mathrm{~F}$ in the absence of carbon. The grain boundaries in the uncarburized sample of Type 318 stainless steel were not revealed by the etchant used.

\section{Plated Type 316 Stainless Steel}

Type 316 stainless steel in contact with graphite permitted carbon to diffuse into the steel during $250-\mathrm{hr}$ tests at $1850 \mathrm{~F}$. In contrast, both nickel and copper reacted very 


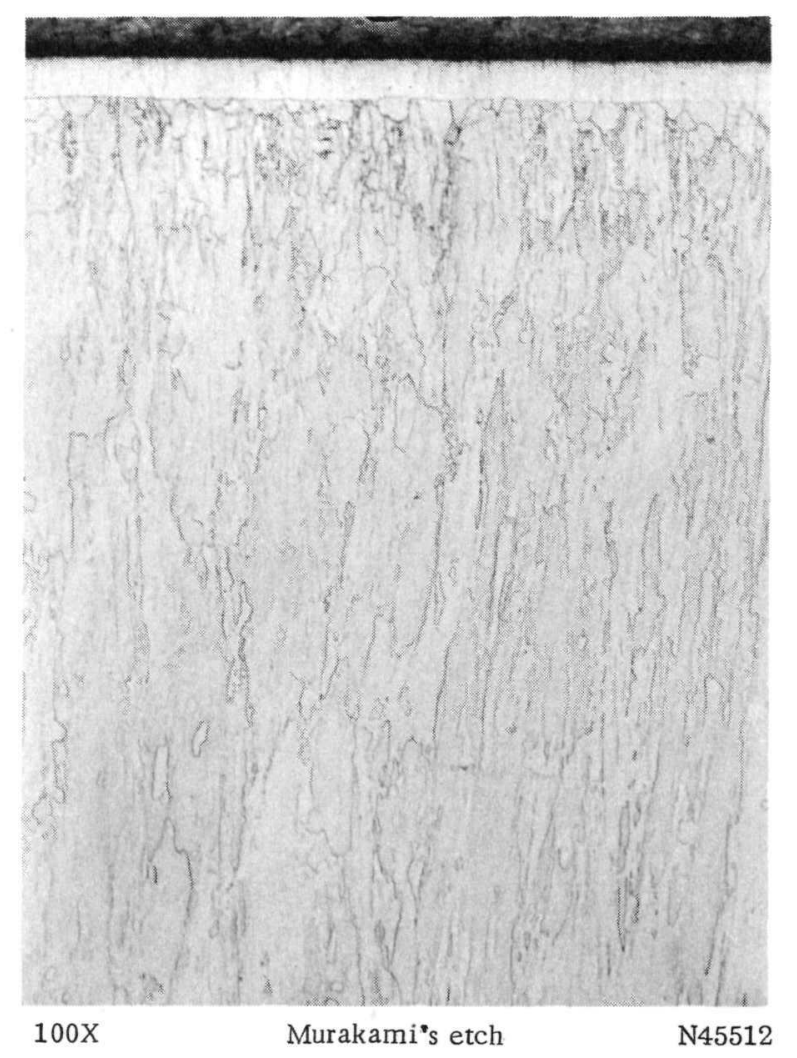

a. Molybdenum

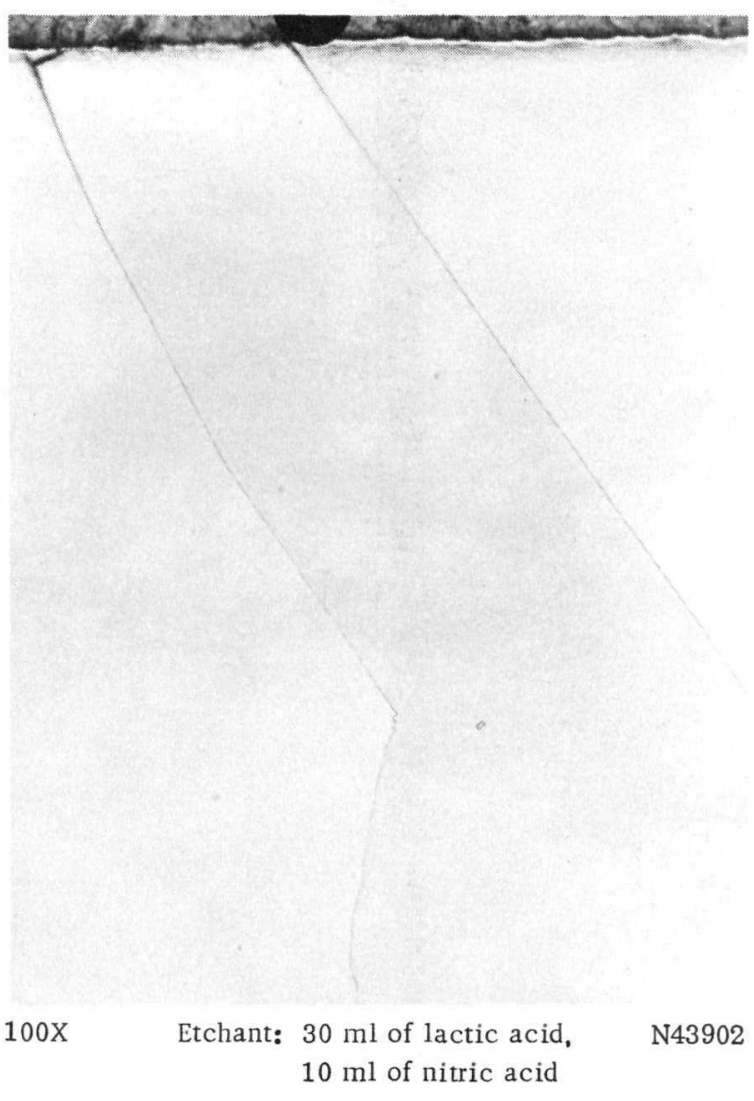

b. Copper

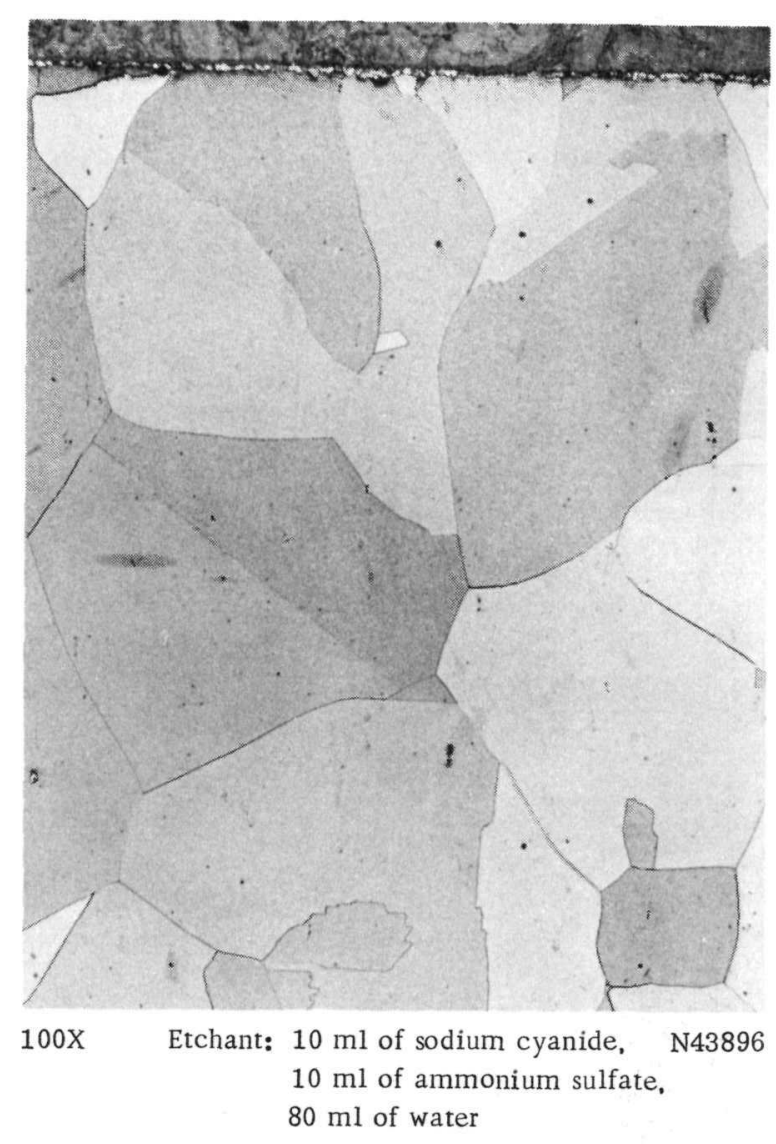

c. Nicke1

FIGURE 1. MICROSTRUCTURES OF THE REGIONS OF CONTACT BETWEEN GRAPHITE AND SEVERAL COMMERCIALLY PURE METALS AFTER REACTION AT $1850 \mathrm{~F}$ FOR $250 \mathrm{HR}$ 


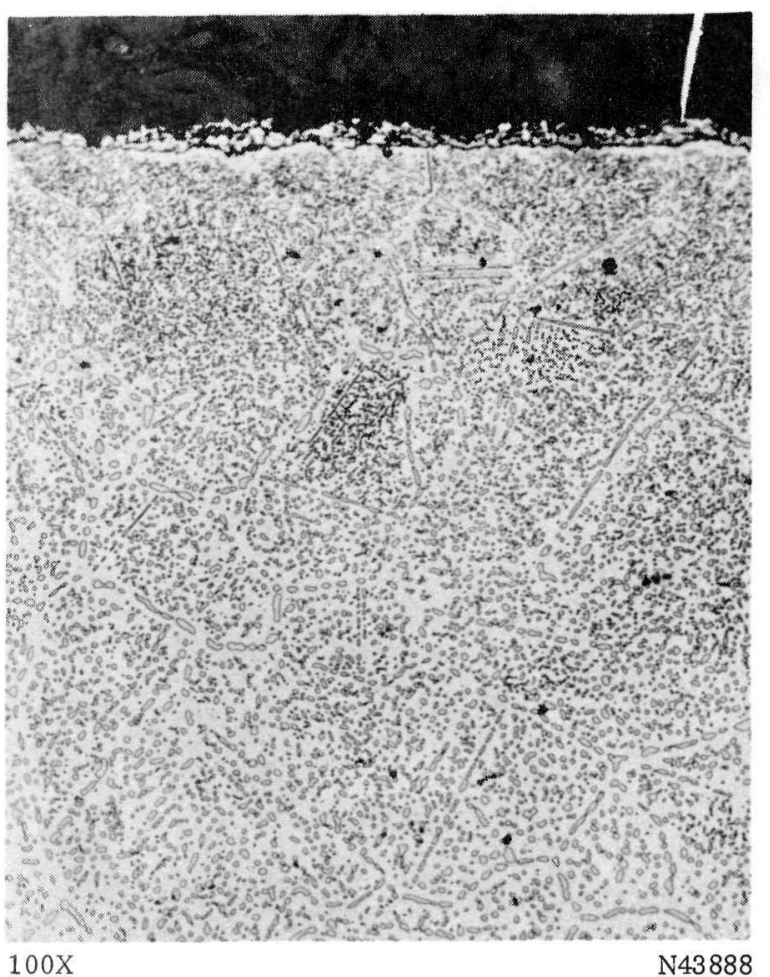

a. Nichrome V

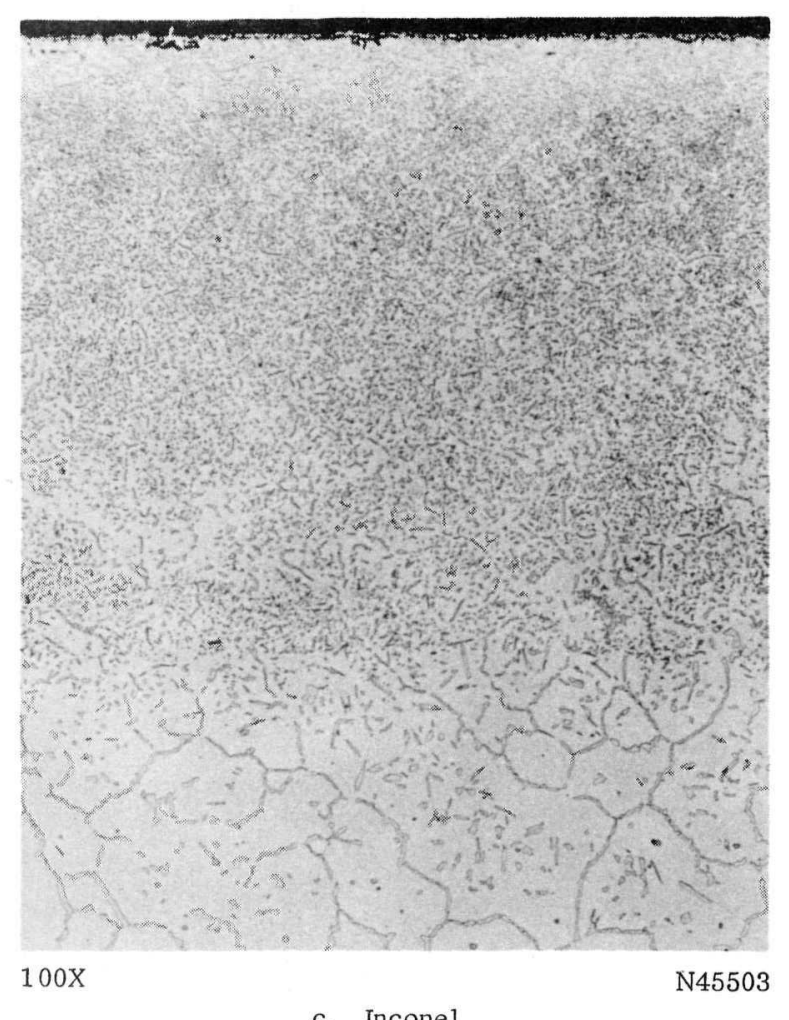

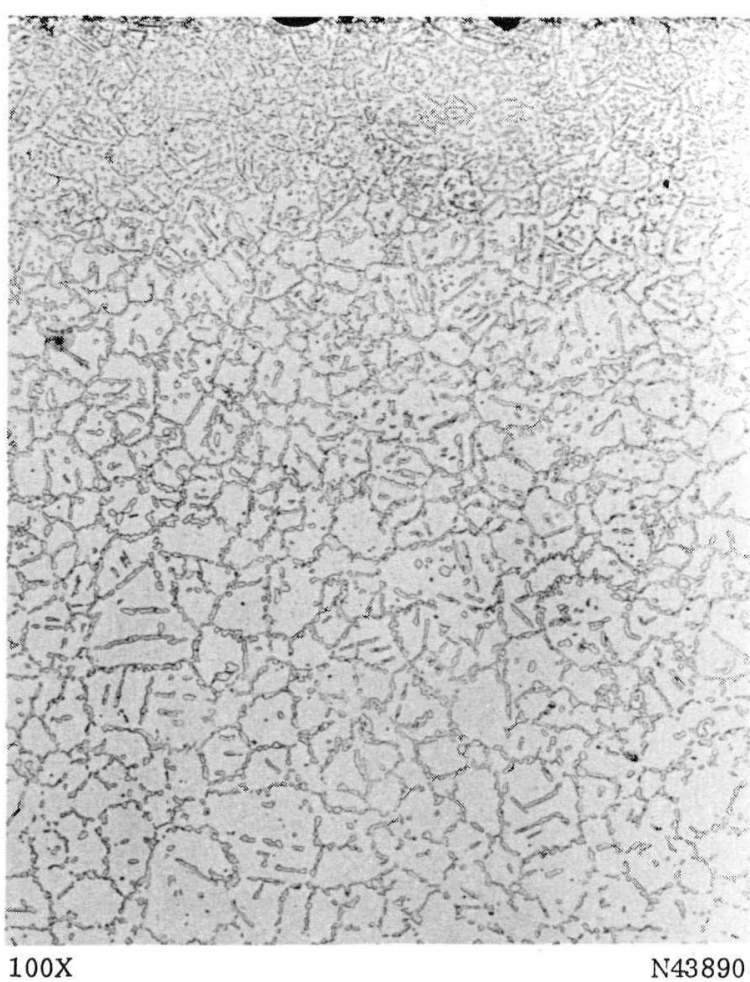

b. Alnicro

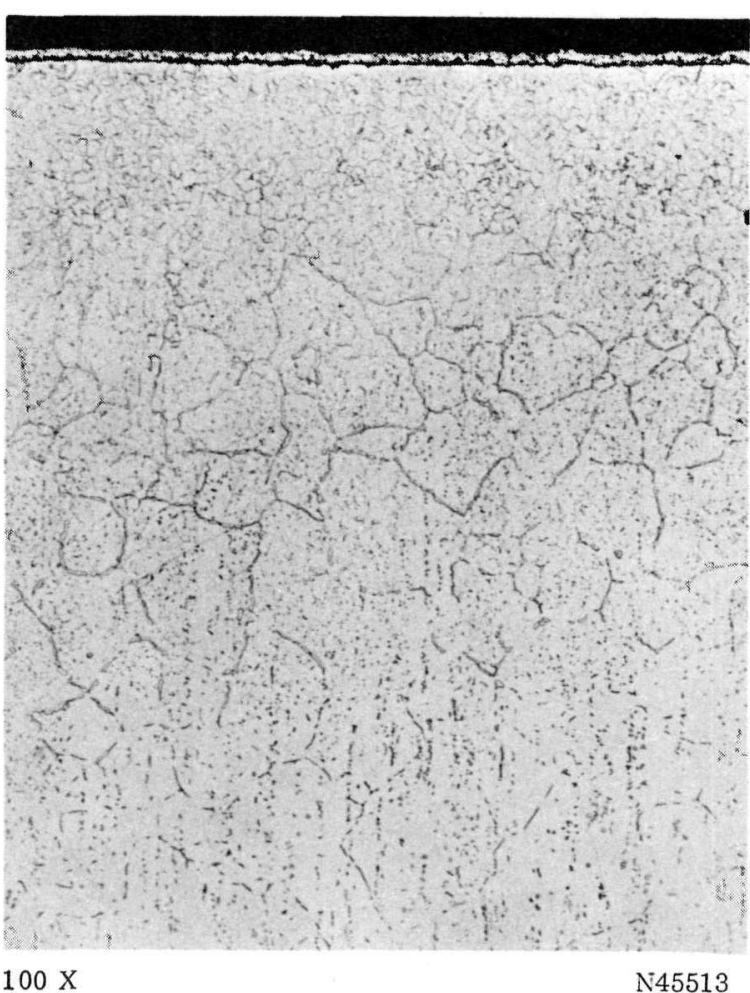

d. Inconel $\mathrm{X}$

FIGURE 2. MICROSTRUCTURES OF THE REGIONS OF CONTACT BETWEEN GRAPHITE AND FOUR NICKEL-BASE ALLOYS AFTER REACTION AT 1850 F FOR 250 HR

Etchant: 4 parts hydrochloric acid and 1 part nitric acid. 
TABLE 2. KNOOP HARDNESSES IN METALS AT KNOWN DISTANCES FROM THE GRAPHITE-METAL INTERFACES AFTER REACTION AT 1850 F FOR 250 HR UNDER PRESSURE

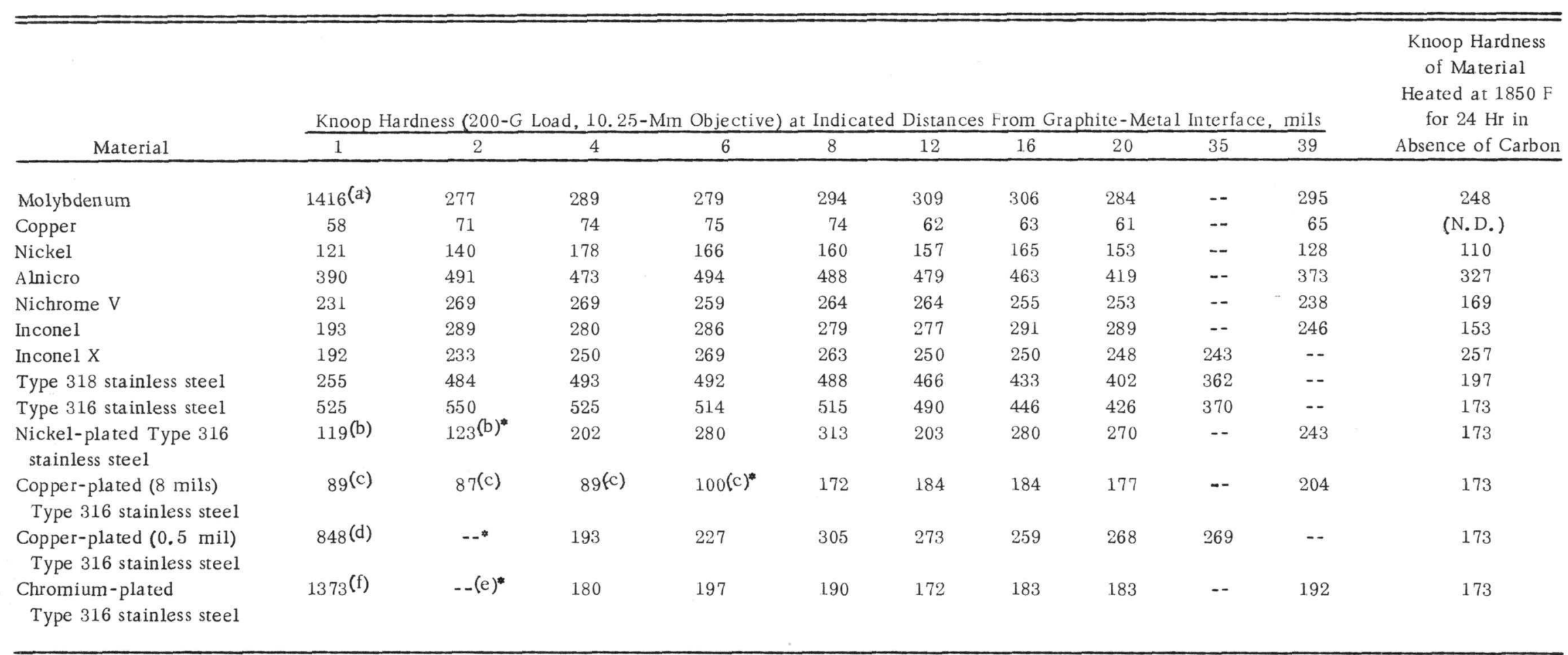

* Hardnesses following are in the test metal.

(a) In hard molybdenum-carbide phases.

(b) In nickel plate.

(c) In 8-mil copper plate. (d) 0.5 -mil copper plate on stainless steel.

(e) Cracked area in hard chromium plate.

(f) In chromium plate.

N.D. - Not detcrmined. 


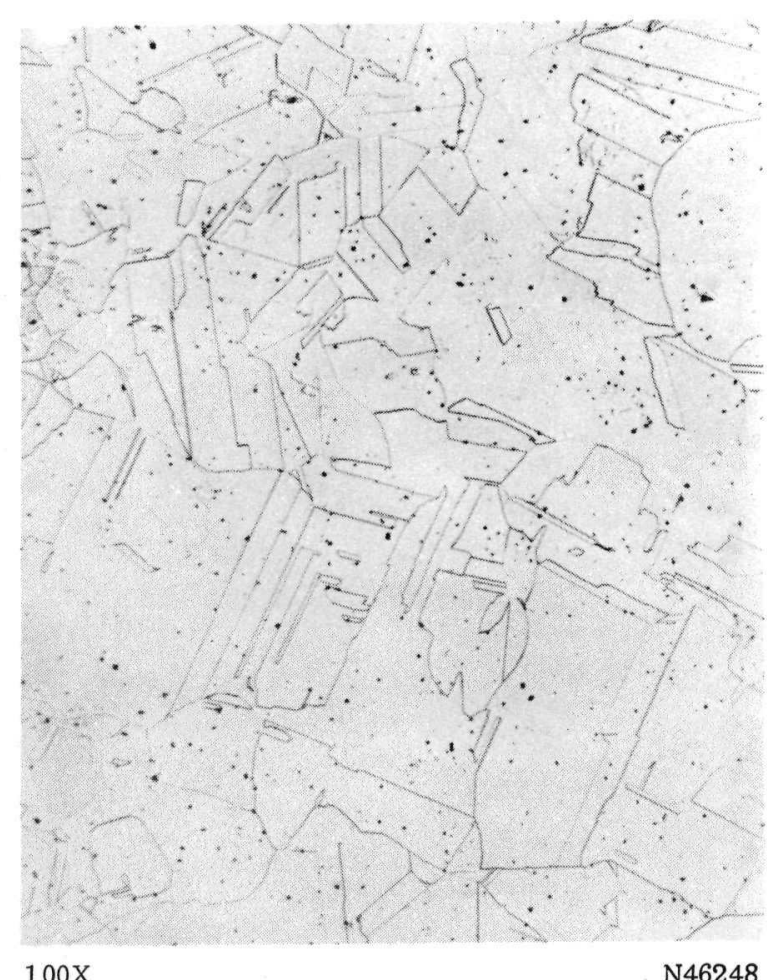

a. Nichrome $\mathrm{V}$

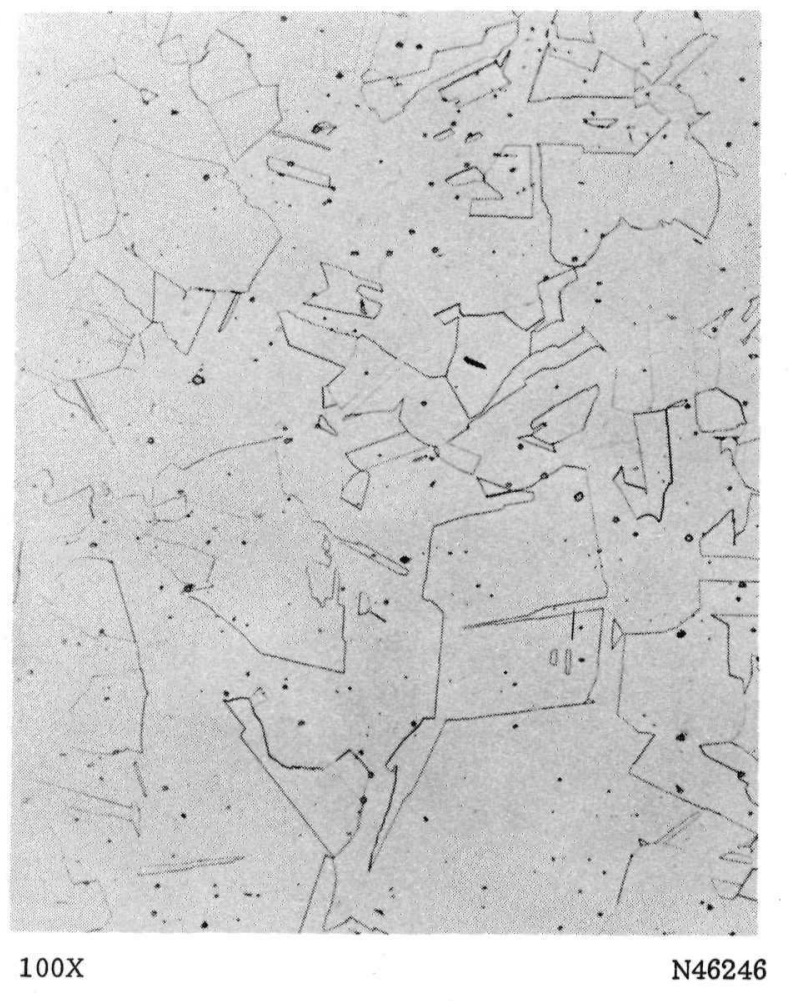

c. Inconel

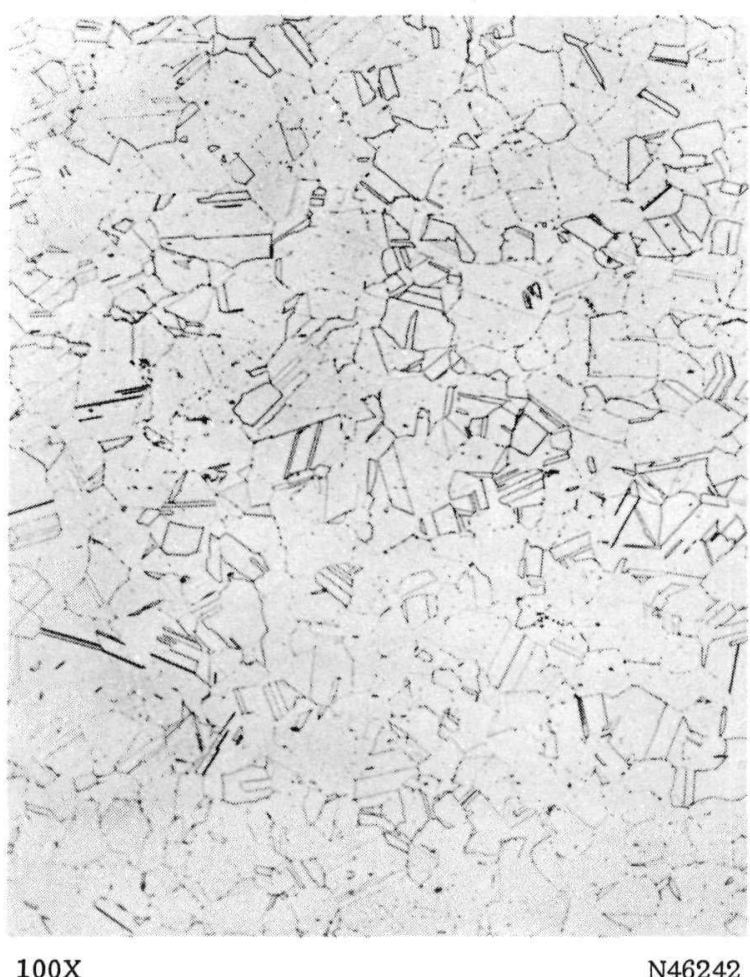

b. Alnicro

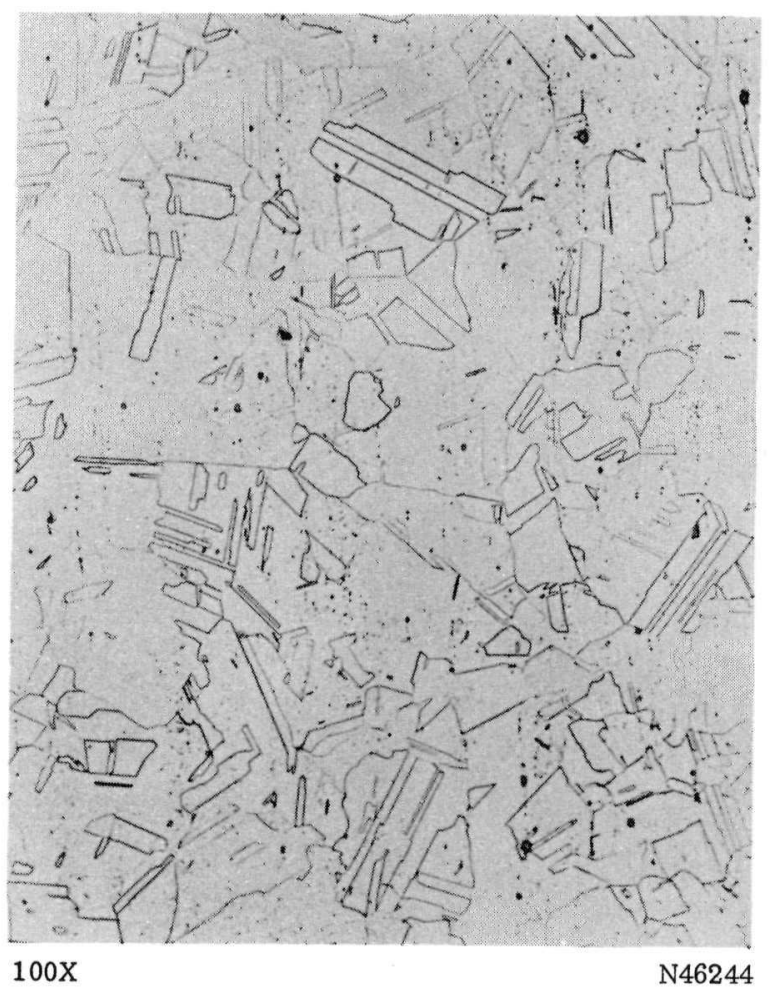

d. Inconel $\mathrm{X}$

FIGURE 3. MICROSTRUCTURES OF NICKEL-BASE ALLOYS HEATED AT 1850 F FOR 24 HR IN ARGON-FILLED CAPSULES IN THE ABSENCE OF GRAPHITE

Etchant: 4 parts hydrochloric acid and 1 part nitric acid. 


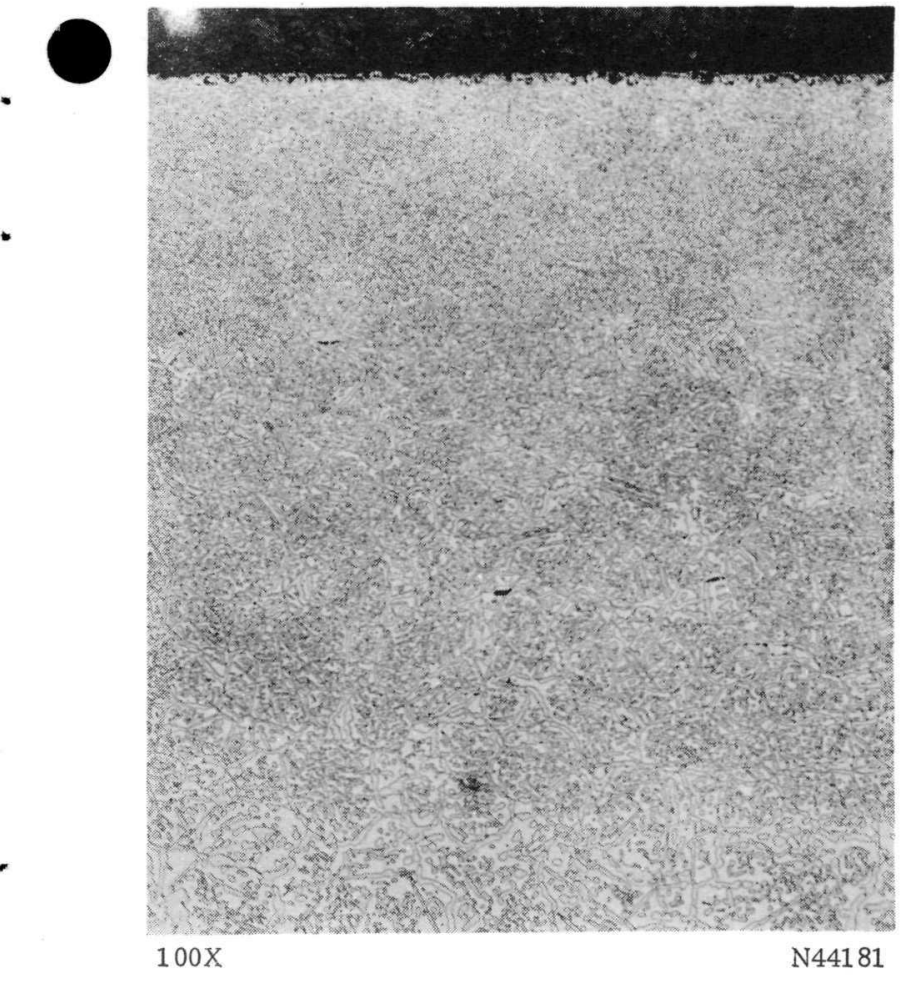

a. Heated in Contact With Graphite at $1850 \mathrm{~F}$ for $250 \mathrm{Hr}$

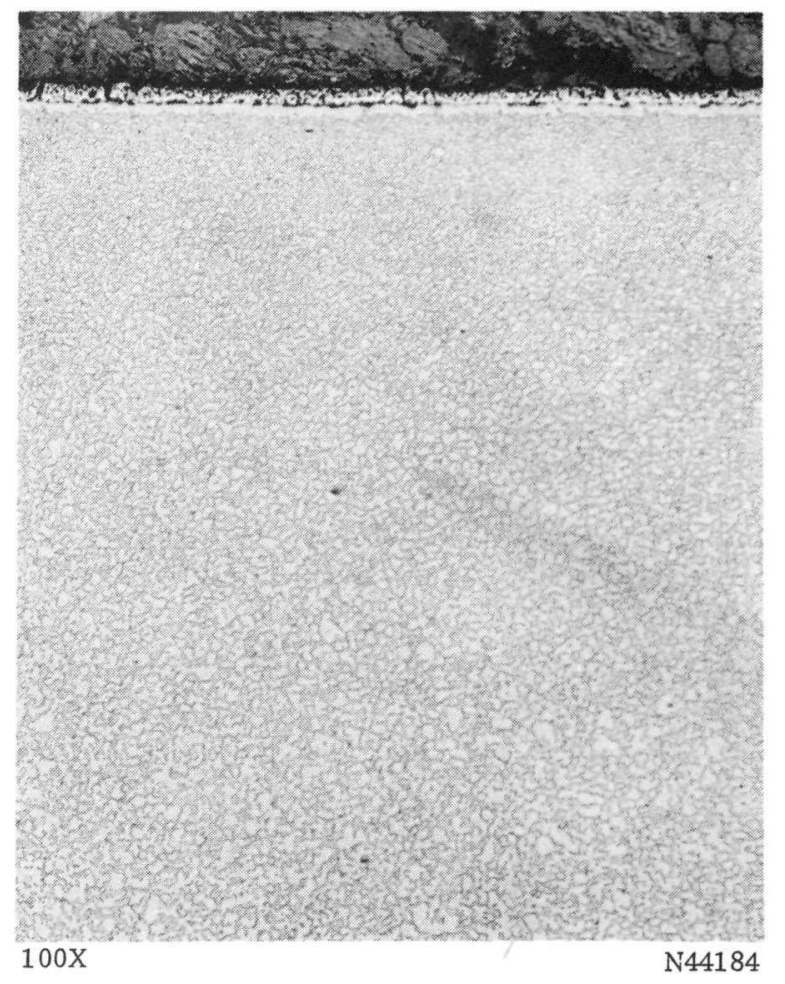

c. Heated in Contact With Graphite at $1850 \mathrm{~F}$ for $250 \mathrm{Hr}$

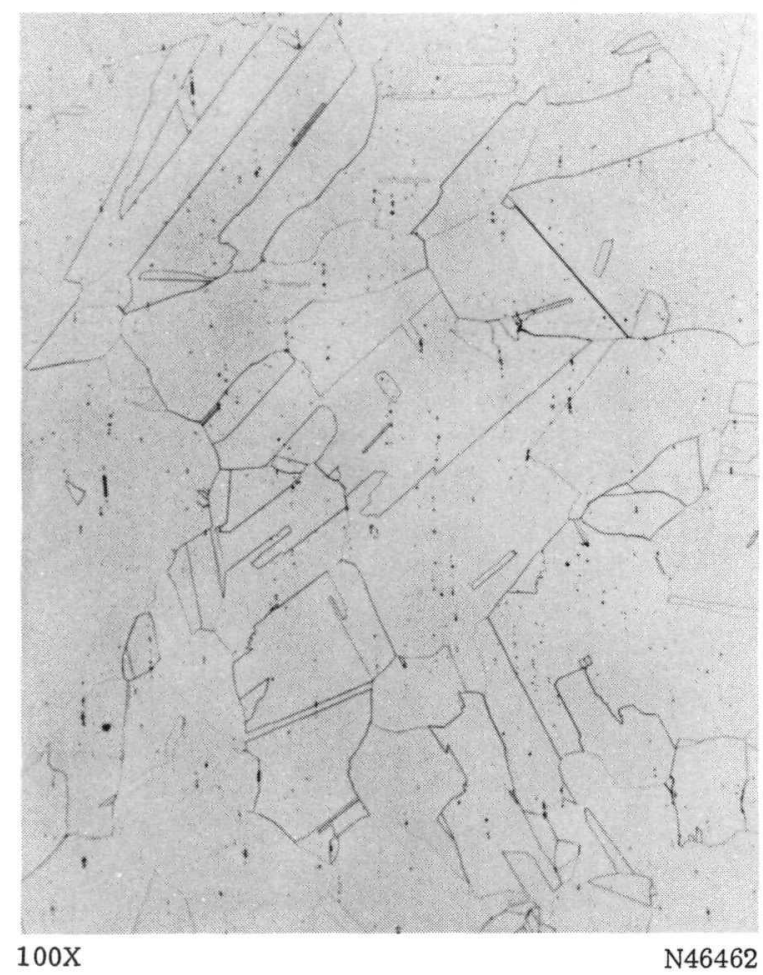

b. Heated in the Absence of Graphite at $1850 \mathrm{~F}$ for $24 \mathrm{Hr}$

Type 316 Stainless Steel

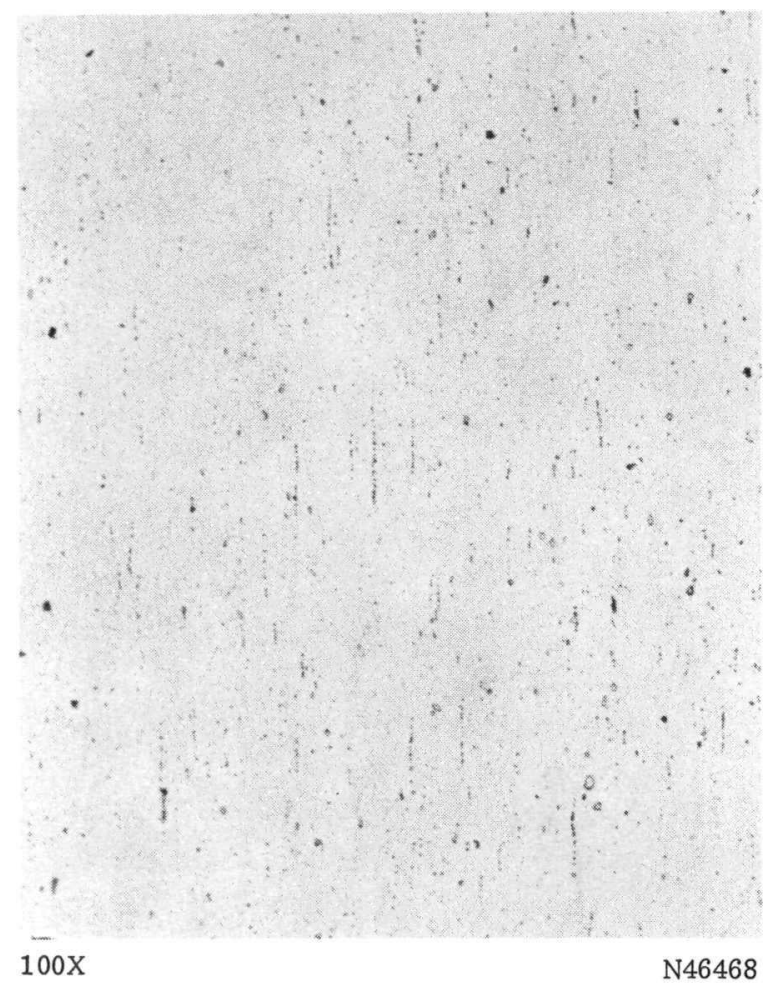

d. Heated in the Absence of Graphite at $1850 \mathrm{~F}$ for $24 \mathrm{Hr}$

Type 318 Stainless Steel

FIGURE 4. MICROSTRUCTURES OF TYPES 316 and 318 STAINLESS STEEL HEATED AT 1850 F WITH AND WITHOUT GRAPHITE Etchant: 4 parts hydrochloric acid and 1 part nitric acid. 
slightly, if at all, under the same conditions. However, copper and nickel are soft and readily deformed at $1850 \mathrm{~F}$. Hence, it was decided to take advantage of their protective properties by using them to plate the stainless steel, which has adequate structural strength. Also chromium was tested as a plating material.

Figure 5 shows that microstructures at the metal-graphite interfaces of the nickel-, copper-, and chromium-plated Type 316 stainless steel after reaction at $1850 \mathrm{~F}$ for $250 \mathrm{hr}$. The nickel plating has remained in the final graphite-metal interface, but carbon has diffused through it into the stainless steel. The depth of penetration is somewhat less than that which took place in the absence of the nickel (see Figure 4a and Table 2). A 0.5-mil-thick copper plate is more effective than a 2.5mil nickel plate in preventing diffusion of carbon into the stainless steel, as is shown in Figure $5 \mathrm{~b}$ and Table 2 . The presence of carbides in the stainless steel is evidence that some carbon had diffused through the copper. An 8-mil copper foil was still more effective than the 0.5 -mil copper plate in retarding diffusion of carbon into the stainless steel, as is shown in Figure $5 \mathrm{c}$ and Table 2.

Figure 5d shows the microstructure of the 4-mil chromium-plated Type 316 stainless steel after reaction with graphite at $1850 \mathrm{~F}$ for $250 \mathrm{hr}$. This microstructure shows that a relatively small amount of carbon has penetrated through the chromium into the stainless steel. The hardness traverse (Table 2) also shows only a slight increase over that of the material heated in the absence of carbon. The relatively hard material at the interface is chromium carbide.

Tests at $1650 \mathrm{~F}$ for $1000 \mathrm{Hr}$

The materials shown to be more resistant to carburization on the basis of the screening tests were subjected to $1000-\mathrm{hr}$ tests at 1650 and $1850 \mathrm{~F}$. Copper was not included in these tests because its melting point is only slightly higher than the test temperature. Commercially pure nickel and molybdenum also were omitted from these tests. Materials tested for $1000 \mathrm{hr}$ at 1650 and $1850 \mathrm{~F}$ were Alnicro, Inconel X, copper-plated Inconel X, Type 316 stainless steel, and copper - and chromium-plated Type 316 stainless steel. Data on the $1650 \mathrm{~F}$ tests follow.

\section{Alnicro and Inconel $\mathrm{X}$}

Figure 6 shows the interfaces of the graphite-Alnicro and the graphite-Inconel $\mathrm{X}$ after reaction. A moderate amount of carbon appears to have diffused into the Alnicro and precipitated out on cooling as carbides, mostly in grain boundaries. The microstructure in the Inconel $\mathrm{X}$ is much finer and for this reason is shown at both $100 \mathrm{X}$ and $250 \mathrm{X}$ in Figures $6 \mathrm{~b}$ and $6 \mathrm{c}$, respectively. Moderate diffusion of carbon into the Inconel $\mathrm{X}$ occurred. The reaction product at the interface is probably a carbide phase. Also, the grain-boundary phase is very probably precipitated carbides since it decreases in quantity with increasing distance from the graphite-Inconel $\mathrm{X}$ interface.

Figure 7 shows the microstructure of the simulated copper-plated Inconel $\mathrm{X}$ after reaction. Instead of plating, a 1.5-mil and an 8-mil copper foil had been inserted between the Inconel $X$ and the graphite. The specimens showed slightly less carburization than did the bare Inconel X. Again, carbide is evident at the interface and as a 


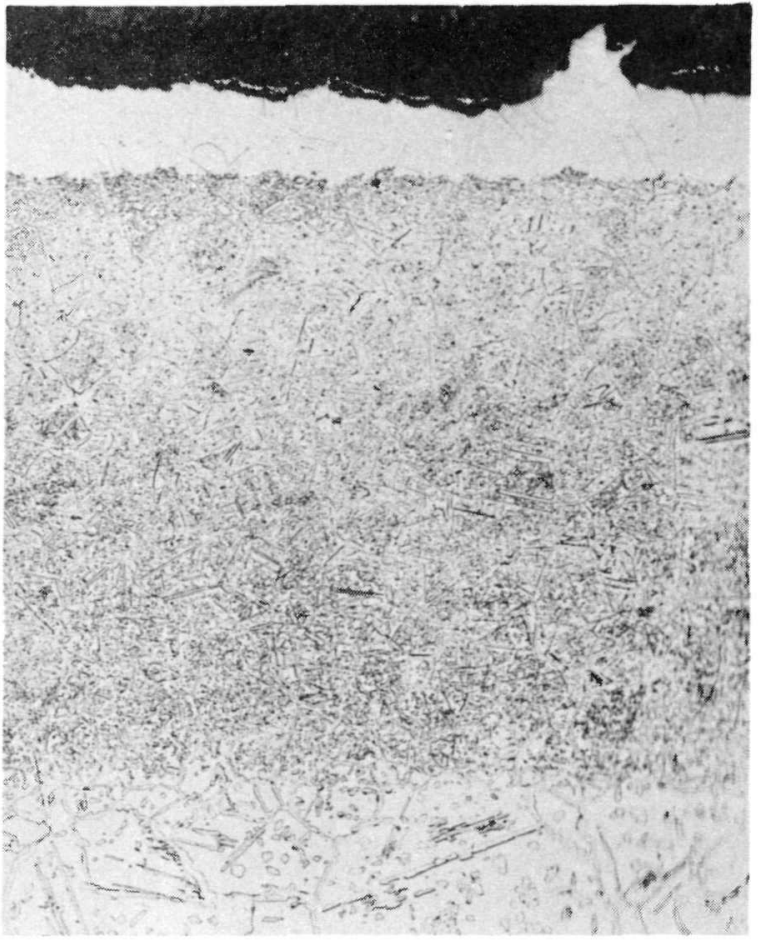

$100 \mathrm{X}$

N44172

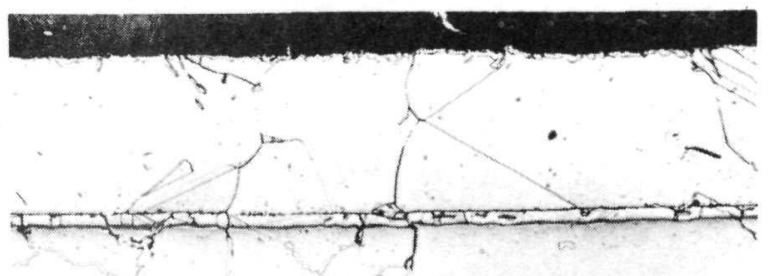

N45509

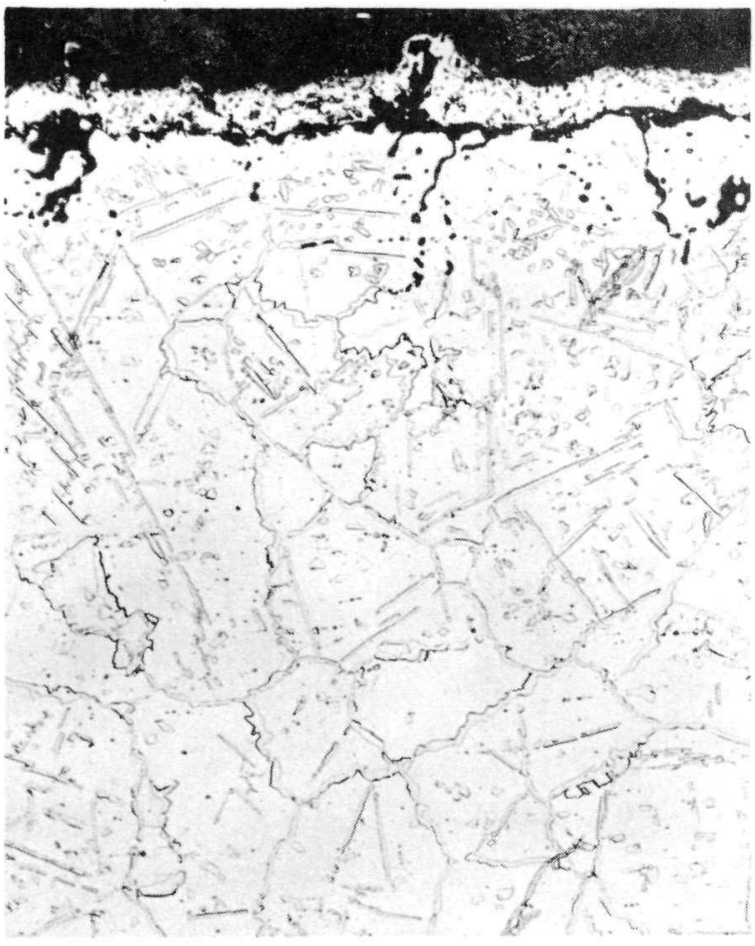

$100 \mathrm{X}$

N44175

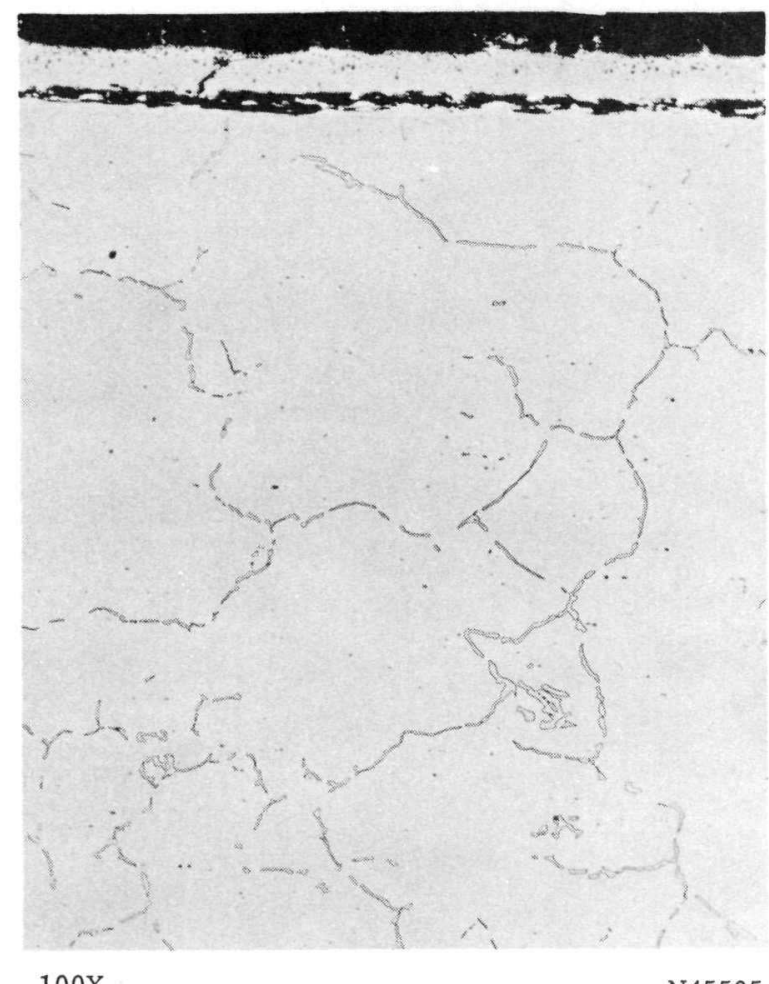

d. 4-Mil Chromium Plate

c. 8-Mil Copper Plate

FIGURE 5. MICROSTRUCTURES OF NICKEL-, COPPER-, AND CHROMIUM-PLATED TYPE 316 STAINLESS STEEL AFTER REACTION WITH GRAPHITE AT 1850 F FOR 250 HR IN ARGON

Etchant: 4 parts hydrochloric acid and 1 part nitric acid. 


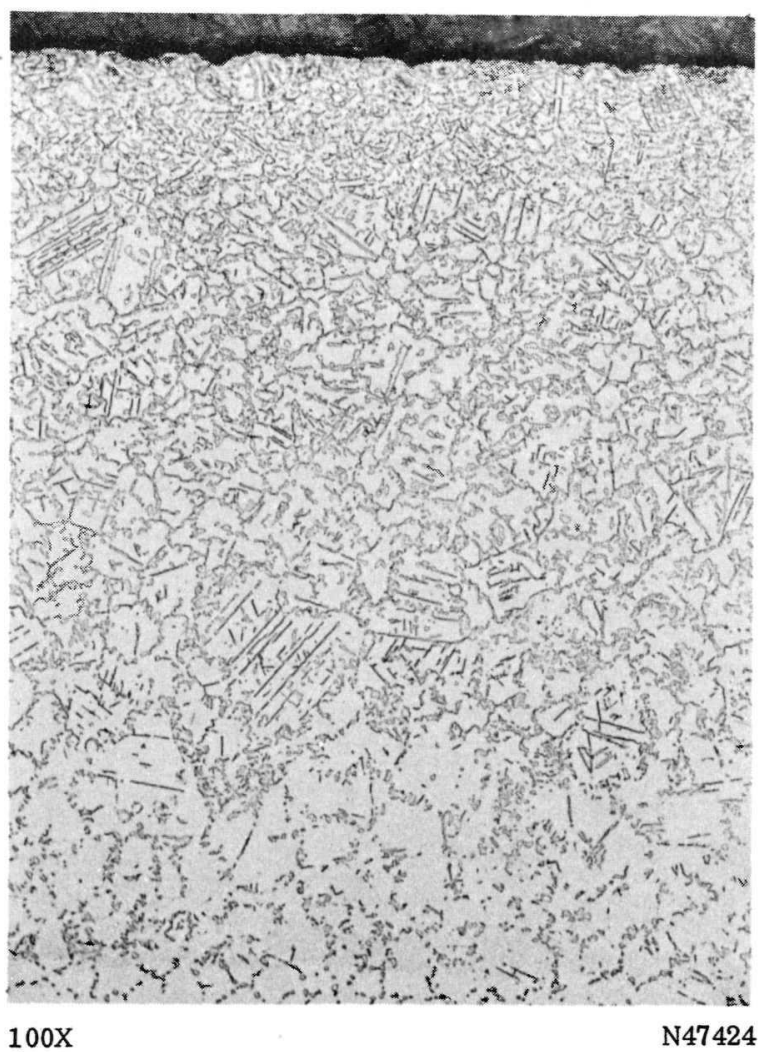

a. Alnicro
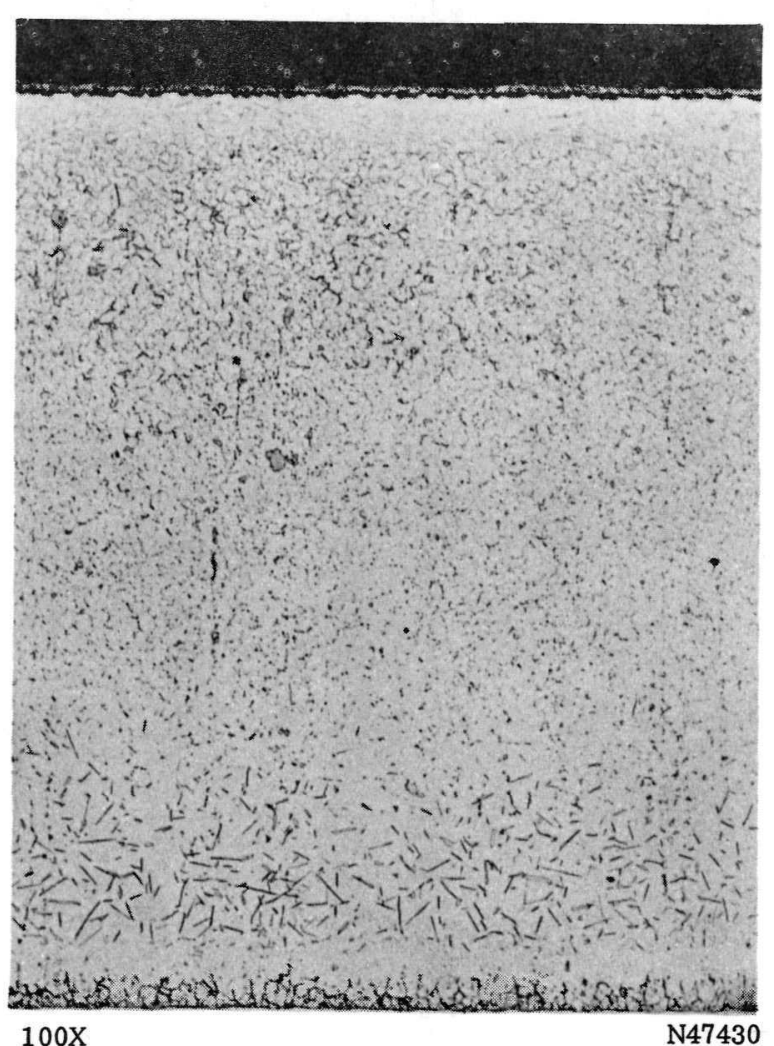

b. Inconel $\mathrm{X}$
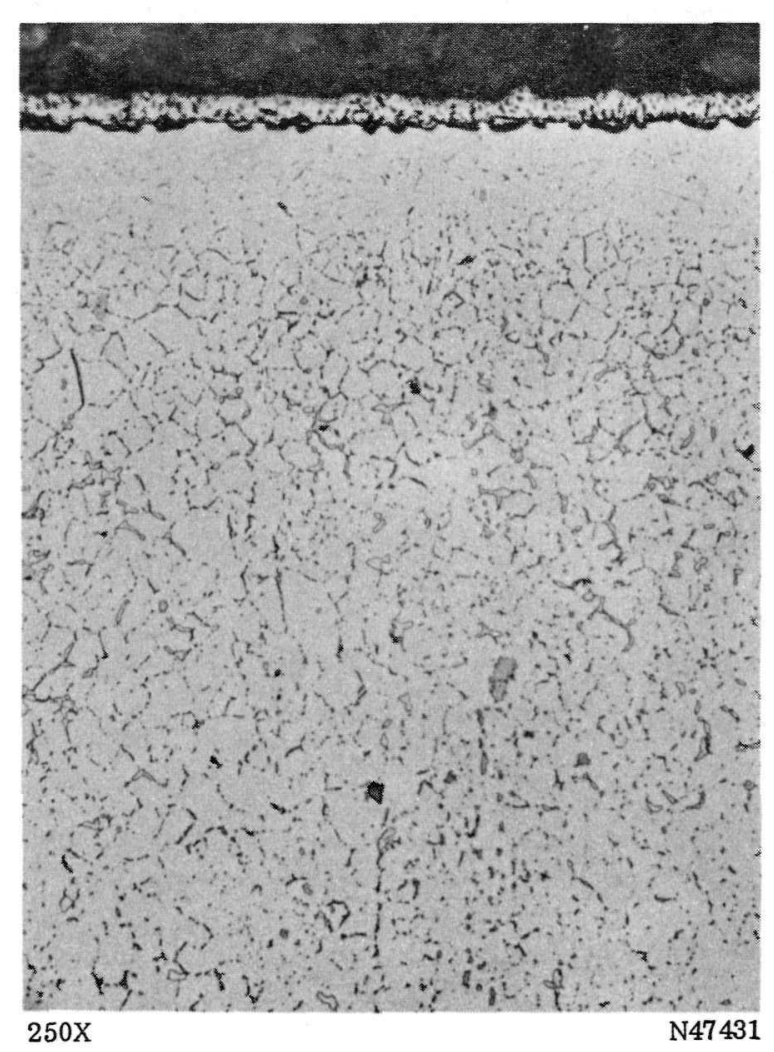

c. Inconel $\mathrm{X}$

FIGURE 6. INTERFACES OF GRAPHITE-ALNICRO AND GRAPHITE-INCONEL X AFTER REACTION AT $1650 \mathrm{~F}$ FOR 1000 HR

Etchant: 4 parts hydrochloric acid and 1 part nitric acid. 


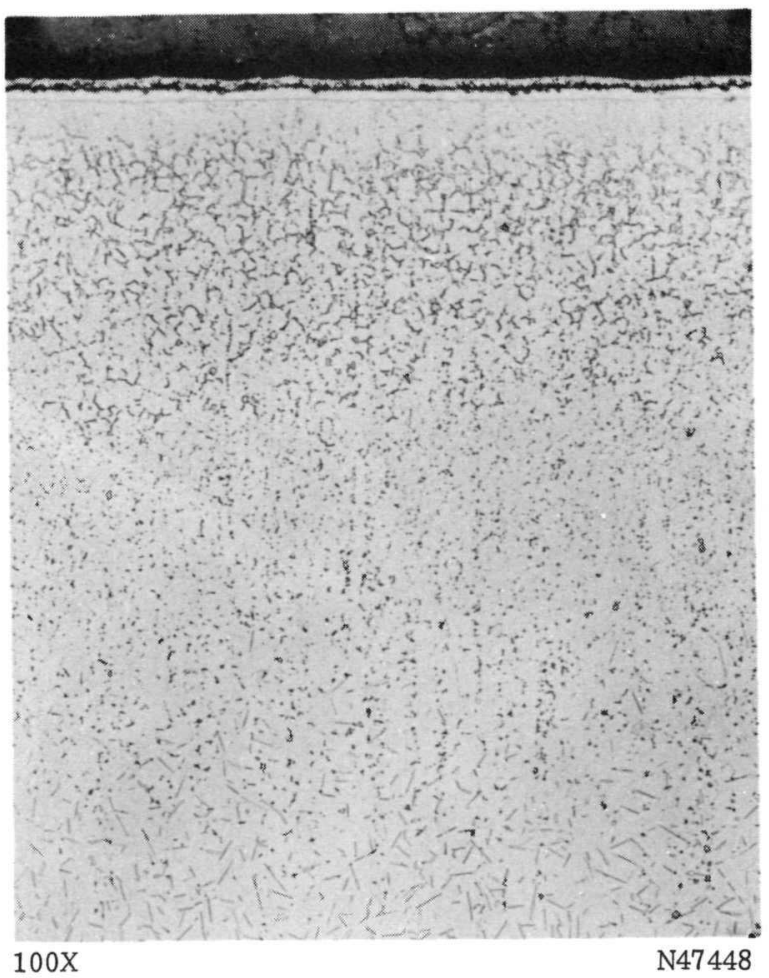

a. 1.5-Mil Copper Foil

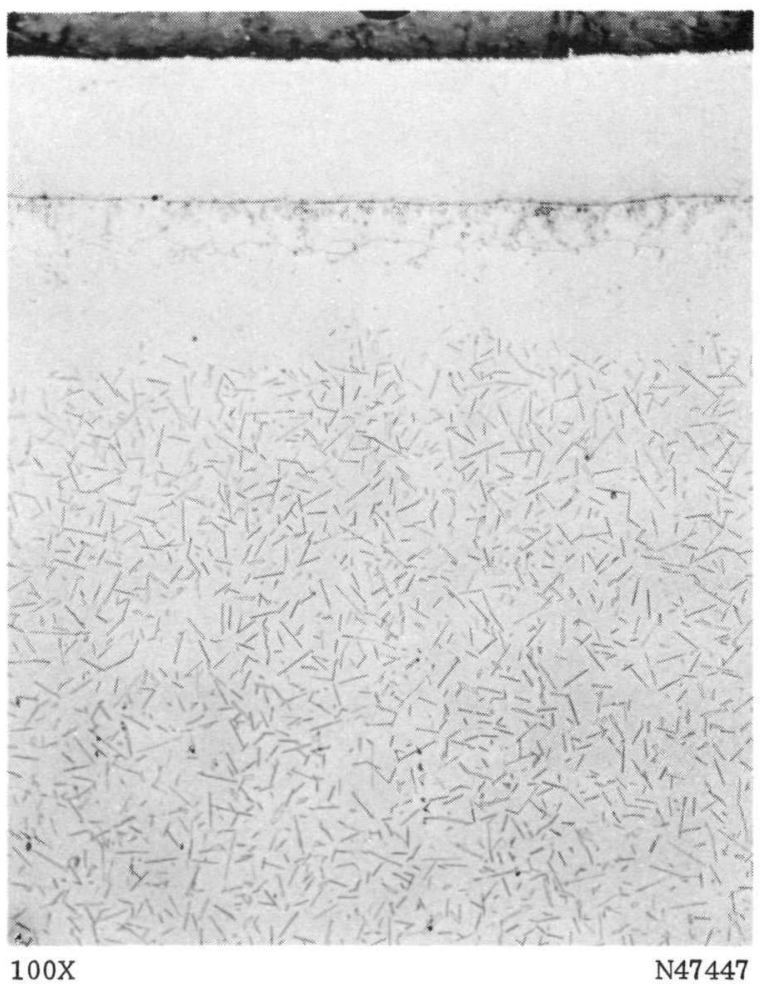

b. 8-Mil Copper Foil

FIGURE 7. INTERFACES OF GRAPHITE-INCONEL X, INITIALLY SEPARATED BY COPPER FOIL, AFTER REACTION AT 1650 FOR 1000 HR

Etchant: 4 parts hydrochloric acid and 1 part nitric acid. 
precipitate in grain boundaries. The 8-mil copper foil was much more effective as a barrier for diffusion of carbon into Inconel $\mathrm{X}$ than the 1.5-mil foil. The 1.5-mil foil lost its integrity by interdiffusion with elements from the Inconel $X$. The light-etching zone adjacent to the copper-Inconel interface may be evidence of diffusion of copper into the Inconel $\mathrm{X}$.

Figure $7 \mathrm{~b}$ shows the structure after reaction of the element containing the thicker foil. The Widmanstätten-type precipitate indicates that the carbon was present in solid solution at $1650 \mathrm{~F}$ and precipitated during the slow quench to room temperature. However, not enough carbon appeared to have diffused into the Inconel X to permit grain-boundary precipitation. A slight amount of the Widmanstätten type of precipitation also was evident considerably farther from the graphite in the unplated Inconel X and also in the element containing the 1.5-mil-thick copper foil (see Figures $6 \mathrm{~b}$ and 7a). In both cases, the carbon contents of these regions were below saturation at $1650 \mathrm{~F}$. Incipient precipitation probably occurred at a lower temperature, where diffusion rates were too low to permit agglomeration of carbide at the grain boundaries.

Results of the hardness traverses on these specimens, shown in Table 3, also bear out these observations. The bare Inconel $\mathrm{X}$ and the Inconel $\mathrm{X}$ having the 1.5-mil copper foil at the interface have very nearly the same hardnesses at equivalent dis tances from the interface. However, the Inconel $X$ protected by the 8 -mil copper foil is somewhat softer at the same distance from the interface.

Alnicro is much harder than Inconel $X$, as is shown by Table 3. Diffusion of carbon into the alloy from the graphite increased its hardness from 120 to $150 \mathrm{Knoop}$ numbers near the interface through formation of a grain-boundary carbide precipitate.

Type 316 Stainless Steel

The microstructure of Type 316 stainless steel after reaction is shown in Figure 8. Because of the fineness of the carbide precipitate near the interface, the structure is shown at $250 \mathrm{X}$ also. Carbide appears to cover 70 per cent of more of the surface area near the interface. The amount of carbides gradually decreases with increasing distance from the graphite. However, carbon appears to have penetrated entirely through the 50-mil-thick Type 316 stainless steel plate and into the Type 303 stainless steel cup.

Results of the hardness traverses shown in Table 3 bear out the metallographic observation. Hardnesses of about 600 Knoop are found up to 20 mils from the interface. The hardness gradually decreases to about 400 Knoop near the interface with the restraining cup.

Figure 9 shows, after reaction, the microstructures of Type 316 stainless steel plated with 1.5- and 8-mil thicknesses of copper and with 2.5- and 6-mil thicknesses of chromium. Some slight diffusion of copper into the graphite is evident. The chromium plating also appeared to diffuse very slightly into the graphite. The 1.5-mil copper plate is less effective than the 8-mil copper plate as a diffusion barrier for carbon. This is evident in the photomicrographs in Figure $9 \mathrm{a}$ and Figure $9 \mathrm{~b}$ and also from the hardness results in Table 3. The 1.5-mil copper foil lost its integrity during the 1000hr reaction at $1650 \mathrm{~F}$. The roughened appearance of the copper foil in Figure 9a is evidence of a mixture of copper and a hard, light-etching phase, probably carbide, 
TAB LE 3. KNOOP HARDNESSES IN METALLIC PHASE AT INDICATED DISTANCES FROM GRAPHITE-METAL INTERFACES IN ELEMENTS HEATED AT 1650 F FOR 1000 HR

\begin{tabular}{|c|c|c|c|c|c|c|c|c|c|c|}
\hline \multirow[b]{2}{*}{ Material } & \multicolumn{10}{|c|}{ Knoop Hardness (a) at Indicated Distance From Graphite-Metal Interface, mils } \\
\hline & 1 & 2 & 4 & 6 & 8 & 12 & 16 & 20 & 30 & 35 \\
\hline Inconel X & 159 (b) & 232 & 272 & 283 & 287 & 272 & 269 & 270 & 265 & 230 \\
\hline Inconel X (1.5-mil copper foil) & $157(\mathrm{c}) *$ & 196 & 291 & 286 & 277 & 272 & 267 & 270 & 268 & 266 \\
\hline Inconel X (8-mil copper foil) & $82(c)$ & $96(c)$ & $109(c)$ & $159(\mathrm{c}) *$ & 203 & 235 & 263 & 269 & 279 & 278 \\
\hline Alnicro & 431 & 470 & 475 & 483 & 475 & 443 & 387 & 384 & 327 & 350 \\
\hline Type 316 stainless steel & 579 & 637 & 640 & 598 & 593 & 535 & 502 & 483 & 429 & 402 \\
\hline $\begin{array}{l}\text { Copper-plated ( } 1.5 \text { mils) } \\
\text { Type } 316 \text { stainless steel }\end{array}$ & 260 & 163 & 275 & 249 & 248 & 295 & 251 & 261 & 269 & 258 \\
\hline $\begin{array}{l}\text { Copper-plated ( } 8 \text { mils) } \\
\text { Type } 316 \text { stainless steel }\end{array}$ & $69(c)$ & $85(c)$ & $83(c)$ & $91(c)$ & $110(\mathrm{c}) *$ & 178 & 181 & 184 & 183 & 176 \\
\hline $\begin{array}{l}\text { Chromium-plated }(2.5 \text { mils }) \\
\text { Type } 316 \text { stainless steel }\end{array}$ & $1363(d)$ & $586 *$ & 169 & 168 & 181 & 192 & 176 & 186 & 205 & 187 \\
\hline $\begin{array}{l}\text { Chromium-plated }(6 \text { mils }) \\
\text { Type } 316 \text { stainless steel }\end{array}$ & $1419(d)$ & $851(d)$ & $194(\mathrm{e})$ & $--(e)^{*}$ & 171 & 173 & 163 & 174 & 173 & 180 \\
\hline
\end{tabular}

* Hardnesses following are in the test metal.

(a) Knoop hardnesses determined with 200 -g load on indenter and $10.25-\mathrm{mm}$ objective lens.

(b) Cracked reaction zone.

(c) In, or partially in, copper plating or copper foil.

(d) In carburized chromium plating.

(e) In unaffected chromium plating. 

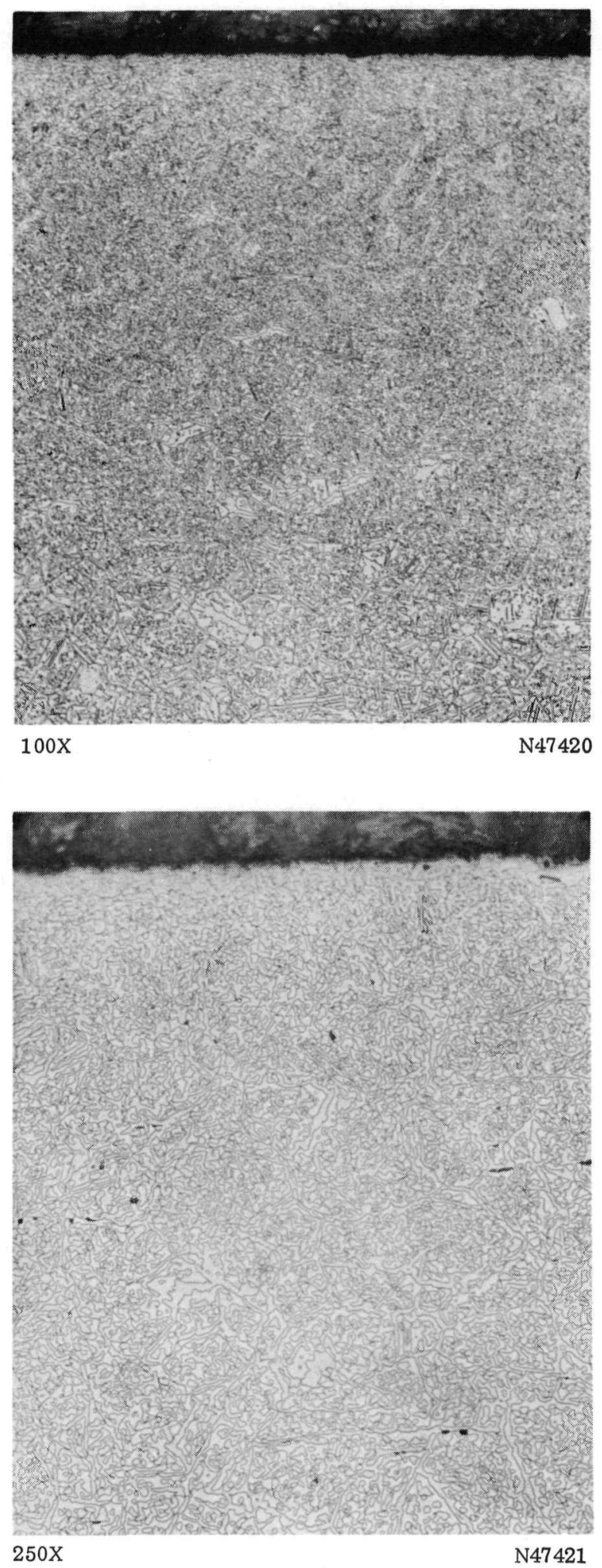

FIGURE 8. INTERFACES OF GRAPHITE-TYPE 316 STAINLESS STEEL AFTER REACTION AT 1650 F FOR 1000 HR Etchant: 4 parts hydrochloric acid and 1 part nitrìc acid. 

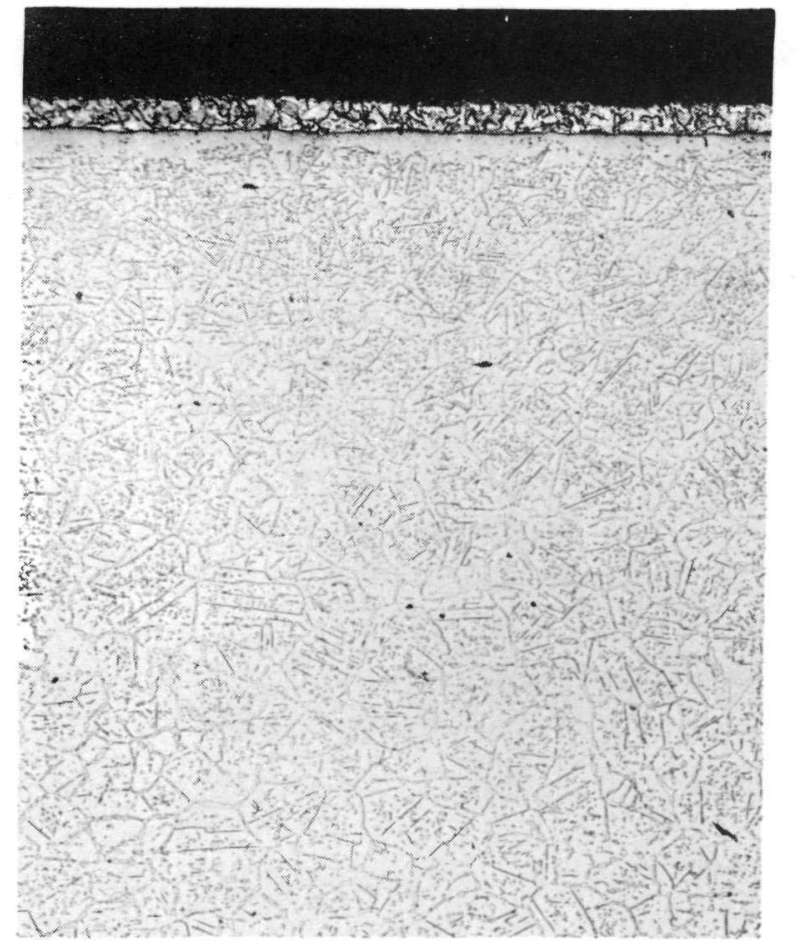

$100 \mathrm{x}$

$\mathrm{N} 47426$

a. 1.5-Mil Copper Plate
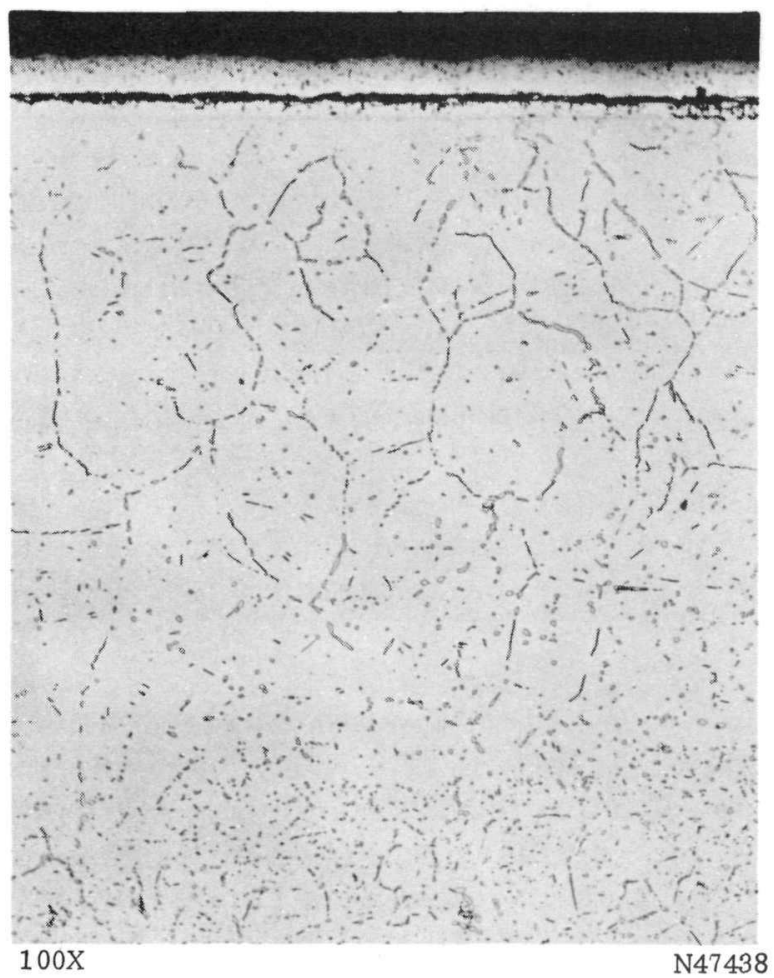

c. 2.5-Mil Chromium Plate

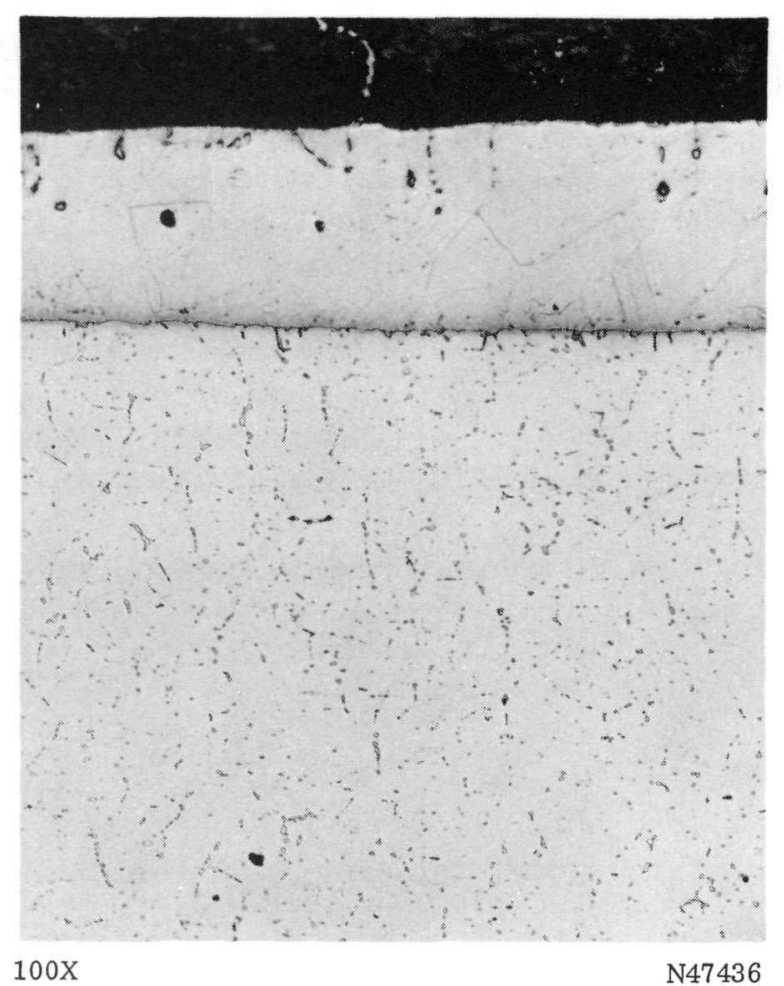

b. 8-Mil Copper Plate
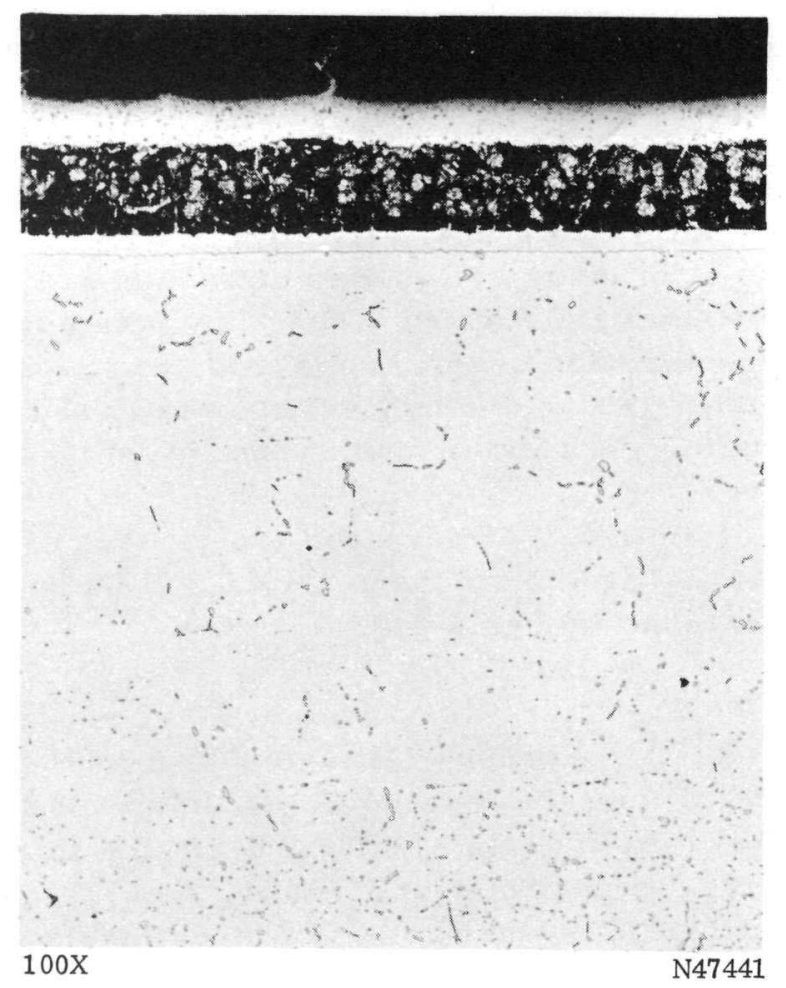

d. 6-Mil Chromium Plate

FIGURE 9. INTERFACES OF GRAPHITE WITH COPPER-PLATED AND CHROMIUM-PLATED TYPE 316 STAINLESS STEEL AFTER REACTION AT 1650 F FOR 1000 HR.

Etchant: 4 parts hydrochloric acid and 1 part nitric acid. 
after reaction. A few of the discrete light-etching particles also are visible in the 8-mil foil in Figure 9b. The very hard metallic phase adjacent to the graphite in Figures $9 c$ and 9d probably contains chromium carbides. The black, etched-out material appears to be uncarburized chromium, while the hard, light-etching phase between the chromium and the stainless steel may be evidence of iron-chromium carbide of the form $(\mathrm{Fe}, \mathrm{Cr})_{3} \mathrm{C}$. The rather broad light-etching region adjacent to the hard band shown in Figure 9d shows only a small amount of a grain-boundary precipitate. This region very probably contains chromium from the plating dissolved in the stainless steel. The 2.5-mil chromium plating appears to be about as effective as the 6-mil chromium plating as a diffusion barrier for carbon on the basis of the hardnesses. However, the photomicrograph in Figure 9c of the specimen with the 2.5-mil chromium plate shows more of the grain-boundary precipitate in the stainless steel near the interface than does the photomicrograph of the specimen with the 6-mil chromium plate shown in Figure 9d.

\section{Tests at $1850 \mathrm{~F}$ for $1000 \mathrm{Hr}$}

The metallic materials selected for the 1000-hr tests were heated simultaneously at 1650 and $1850 \mathrm{~F}$ in contact with graphite. As might be expected, all of the materials reacted more extensively with graphite at $1850 \mathrm{~F}$ than at $1650 \mathrm{~F}$. Data on the $1850 \mathrm{~F}$ tests follow.

$\underline{\text { Alnicro and Inconel } \mathrm{X}}$

Figure 10 shows the microstructures at the graphite-Alnicro and the graphiteInconel $\mathrm{X}$ interfaces after reaction at $1850 \mathrm{~F}$. As might be expected, somewhat more carbon diffused into the alloys at $1850 \mathrm{~F}$ than at $1650 \mathrm{~F}$, as is evidenced by the formation of broader and more continuous grain-boundary-carbide envelopes. Both Alnicro and Incone $1 \mathrm{X}$ showed a reaction band adjacent to the graphite and very slight evidence of penetration of the alloys into the graphite. The gray band in the Inconel $\mathrm{X}$ adjacent to the interface, most clearly shown at 250X, is similar in appearance to some of the isolated gray inclusions in the Inconel $\mathrm{X}$.

Both the Alnicro and the Inconel $\mathrm{X}$ show a deeper and somewhat harder zone after reaction at $1850 \mathrm{~F}$ than at $1650 \mathrm{~F}$. This can be seen by comparing the data in Table 4 with those in Table 3.

The microstructures at $100 \mathrm{X}$ of samples in which graphite was separated from Inconel $\mathrm{X}$ by copper foil are shown in Figure 11 after reaction at $1850 \mathrm{~F}$. Both the 1. 5-mil and the 8-mil foils at the graphite-Inconel X interface lost their integrities by interdiffusion with elements from the Inconel $X$, since neither foil retained its characteristic coppery color. Again, the 1.5-mil foil was less effective as a barrier for carbon than the 8-mil foil. However, it is obvious from the carbides in the grain boundaries in the Inconel $X$ that diffusion of carbon did occur. The 1.5-mil foil apparently was somewhat effective as a diffusion barrier for carbon, as seen from comparative hardness data in Table 4. It appears likely that diffusion of copper into the Inconel X decreased the effectiveness of the copper as a diffusion barrier for carbon. 


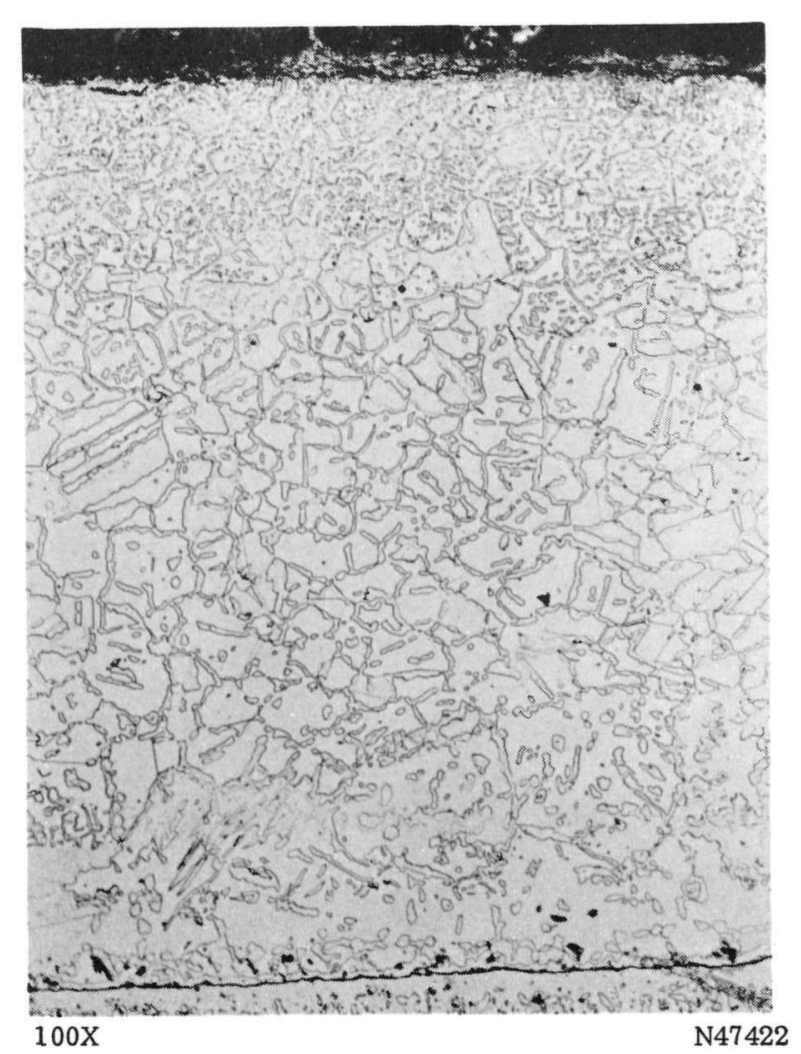

a. Alnicro

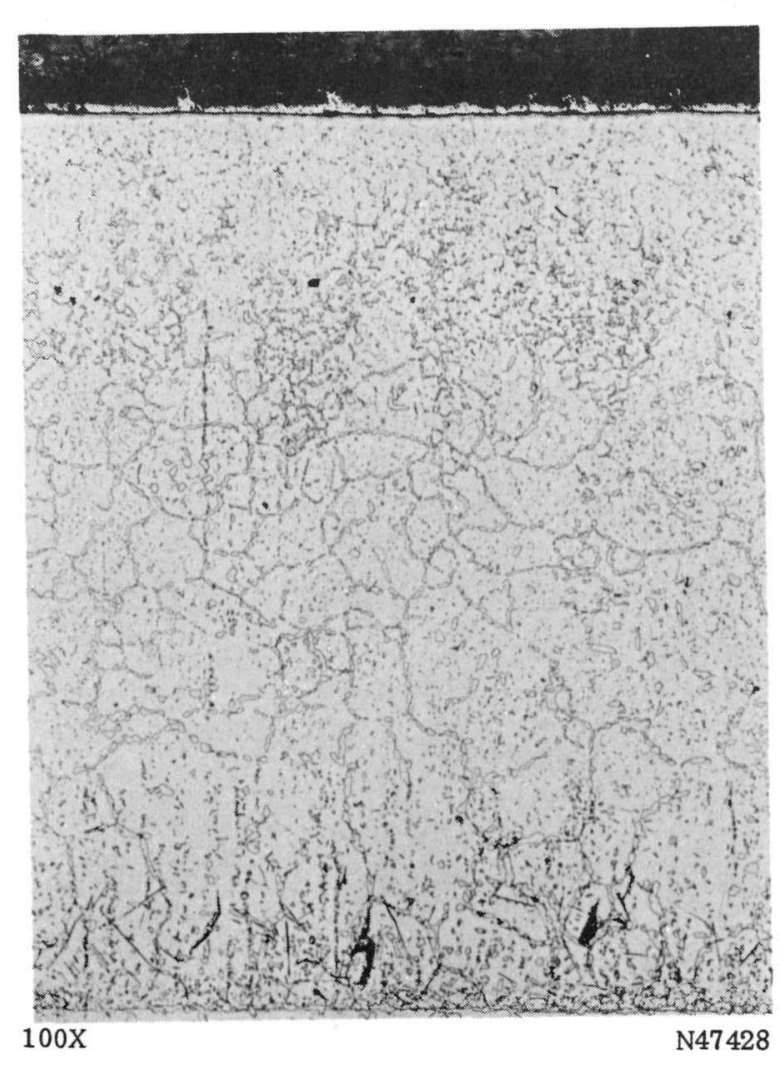

b. Inconel $\mathrm{X}$

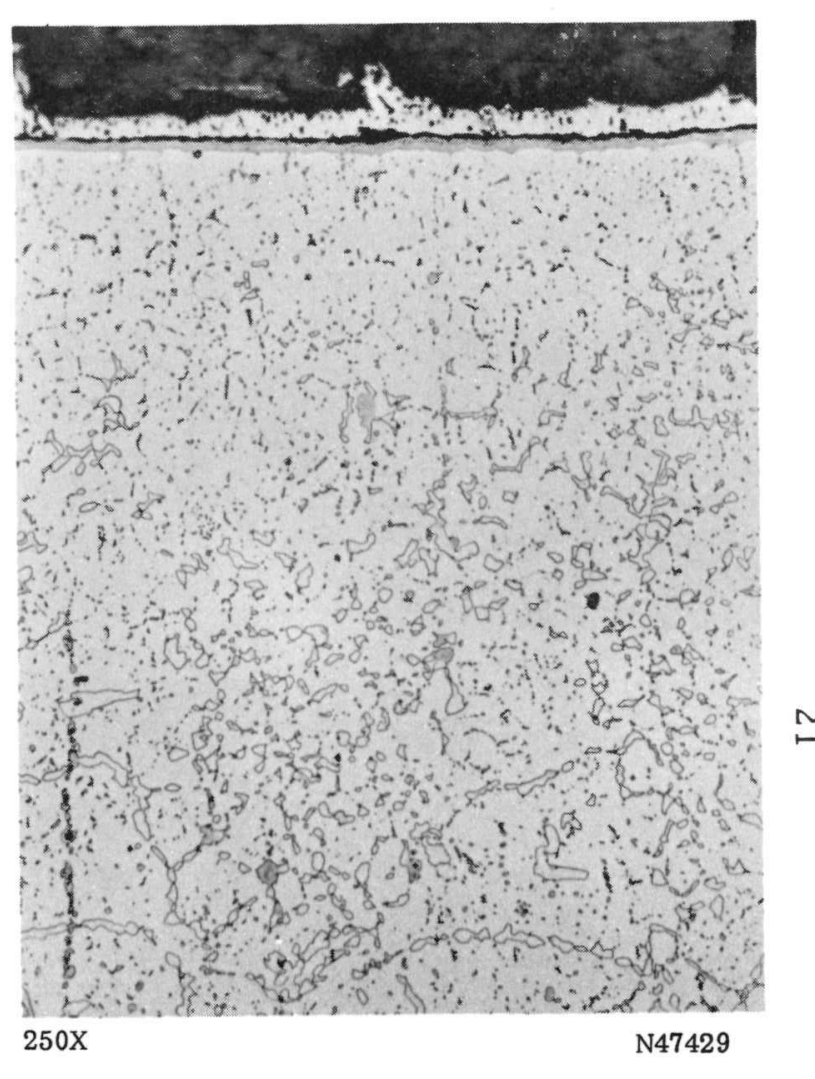

c. Inconel $x$

FIGURE 10. INTERFACES OF GRAPHITE WITH ALNICRO AND INCONEL X AFTER REACTION AT $1850 \mathrm{~F}$ FOR 1000 HR

Etchant: 4 parts hydrochloric acid and 1 part nitric acid. 
TABLE 4. HARDNESSES IN METALLIC PHASES AT INDICATED DISTANCES FROM GRAPHITE-METAL INTERFACES IN ELEMENTS HEATED AT 1850 F FOR 1000 HR

\begin{tabular}{|c|c|c|c|c|c|c|c|c|c|c|}
\hline \multirow[b]{2}{*}{ Material } & \multicolumn{10}{|c|}{ Knoop Hardness (a) at Indicated Distance From Graphite-Metal Interface, mils } \\
\hline & 1 & 2 & 4 & 6 & 8 & 12 & 16 & 20 & 30 & 35 \\
\hline Inconel $\mathrm{X}$ & 210 & 232 & 264 & 304 & 321 & 335 & 307 & 314 & 296 & -- \\
\hline Inconel X (1.5-mil copper foil) & $221(\mathrm{~b}) *$ & 209 & 254 & 251 & 298 & 290 & 308 & 293 & 290 & 300 \\
\hline Inconel X (8-mil copper foil) & $151(\mathrm{~b})$ & $127(\mathrm{~b}) *$ & 172 & 167 & 203 & 267 & 263 & 252 & 286 & 297 \\
\hline Alnicro & (c) & (c) & 400 & 473 & 485 & 507 & 529 & 511 & 470 & 413 \\
\hline Type 316 stainless steel & (c) & 592 & 530 & 545 & 547 & 521 & 505 & 498 & 483 & 464 \\
\hline $\begin{array}{l}\text { Copper-plated ( } 1.5 \text { mils) } \\
\text { Type } 316 \text { stainless steel }\end{array}$ & (b) & $119(\mathrm{~b}) *$ & 382 & 415 & 380 & 391 & 330 & 366 & 371 & 368 \\
\hline $\begin{array}{l}\text { Copper-plated ( } 8 \text { mils) } \\
\text { Type } 316 \text { stainless steel }\end{array}$ & $158(\mathrm{~b})$ & $132(\mathrm{~b})$ & $110(\mathrm{~b})$ & $114(b)$ & $117(\mathrm{~b}) *$ & 387 & 390 & 403 & 349 & 334 \\
\hline $\begin{array}{l}\text { Chromium-plated }(2.5 \mathrm{mils}) \\
\text { Type } 316 \text { stainless steel }\end{array}$ & $1372(d)$ & $1530(\mathrm{~d}) *$ & 368 & 427 & 438 & 396 & 346 & 451 & 363 & 355 \\
\hline $\begin{array}{l}\text { Chromium-plated (6 mils) } \\
\text { Type } 316 \text { stainless steel }\end{array}$ & $1414(d)$ & $1881(\mathrm{~d})$ & $--(e)$ & $1770(d) * *$ & 331 & 455 & 333 & 368 & 417 & 383 \\
\hline
\end{tabular}

* Hardnesses following are in test metals.

(a) Knoop hardnesses determined with 200-g load on indenter and 10.25-mm objective lens.

(b) In copper plate or foil.

(c) Cracked.

(d) In chromium plate.

(e) In etched out uncarburized chromium. 


\section{3}

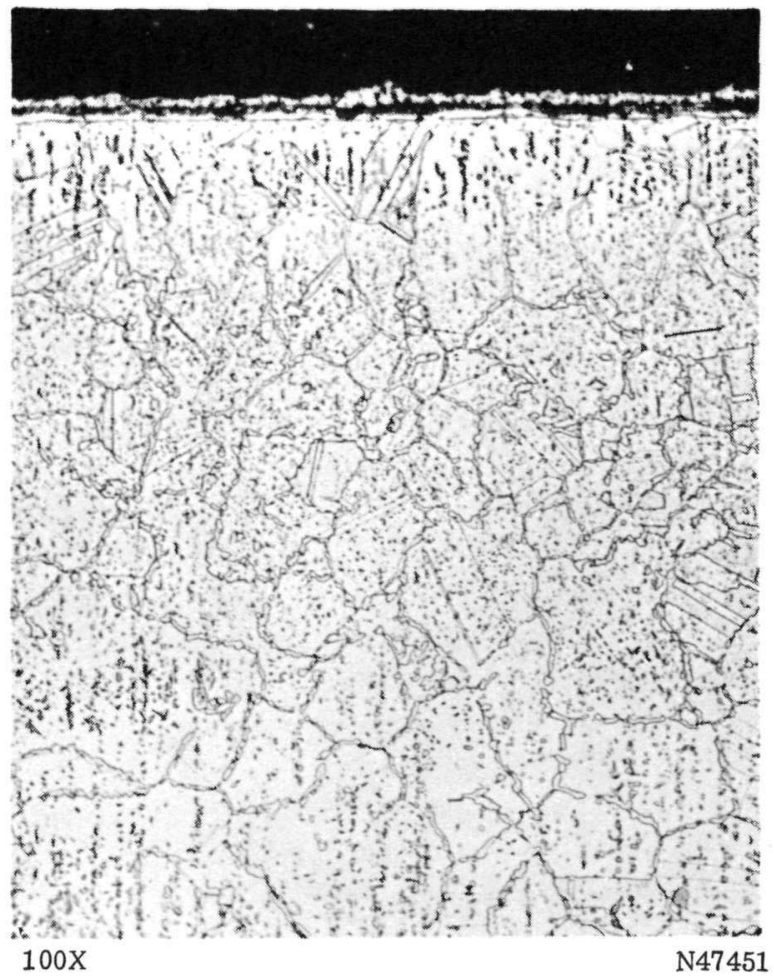

a. 1.5-Mil Copper Foil

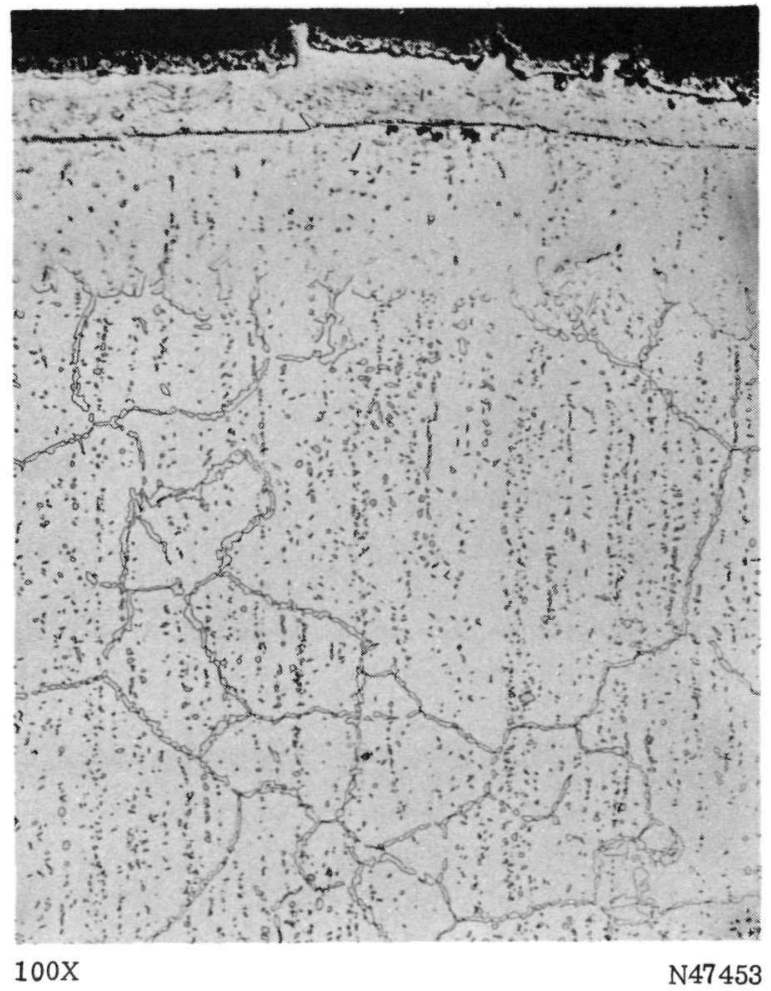

b. 8-Mil Copper Foil

FIGURE 11. INTERFACES OF GRAPHITE-INCONEL X INITIALLY SEPARATED BY COPPER FOIL AFTER REACTION AT $1850 \mathrm{~F}$ FOR $1000 \mathrm{HR}$

Etchant: 4 parts hydrochloric acid and 1 part nitric acid. 
Type 316 Stainless Steel

Figure 12 shows the microstructure in the Type 316 stainless steel after reaction. In addition to a reaction zone at the interface, diffusion of carbon into the stainless steel is evidenced by the precipitated carbides in the grain boundaries and also within the grains of the steel. The carbides produced hardnesses in the steel of about 550 Knoop, as shown in Table 4.

Figure 13 shows the microstructures at the interfaces of copper-and chromiumplated Type 316 stainless steel after reaction. These microstructures indicate that both chromium and copper are somewhat effective as barriers for the diffusion of carbon into Type 316 stainless steel at $1850 \mathrm{~F}$. Carbides are present in grain boundaries and also within the grains of the steel after reaction. However, the plated steel does not show as much of the carbide phase as the unplated steel does (see Figure 12). The thin 1.5-mil copper plate completely lost its characteristic coppery color as a result of the $1000-\mathrm{hr}$ heating at $1850 \mathrm{~F}$. The 8 -mil foil retained its coppery color but showed evidence for diffusion of copper into the stainless. In addition, a thin, light-etching, apparently hard phase is adjacent to the graphite, and some discrete light-etching particles are present in the copper foil. It is difficult to decide from the photomicrographs whether chromium or copper is the best barrier material to prevent carbon diffusion. Slightly lower hardnesses, however, were obtained in the copper-plated specimen than in the chromium-plated specimen, as is shown in Table 4 . The etchedout region in the 6-mil chromium-plated specimen is probably evidence of uncarburized chromium.

\section{CONCLUSIONS}

Based on metallographic and hardness studies, the following conclusions may be drawn about the reaction of graphite with metals and alloys on the basis of the 250 and 1000-hr tests at $1850 \mathrm{~F}$ :

(1) Of the several metals and alloys tested, copper is the material most resistant to attack by carbon. Nickel is only slightly more reactive than copper in the 250-hr test. Molybdenum forms carbides at the interface but shows no evidence of penetration of carbon into molybdenum beyond the carbide layer.

(2) Of the alloys studied, Inconel $\mathrm{X}$ appears least affected by reaction with carbon when heated in contact with graphite. Alnicro is less resistant than Inconel $\mathrm{X}$ but better than Nichrome $\mathrm{V}$, Inconel, and Types 316 and 318 stainless steel. Both Inconel $X$ and Alnicro appear promising materials for use in contact with graphite up to about $1850 \mathrm{~F}$.

(3) Copper, chromium, and, to a much lesser extent, nickel are effective as barriers for the diffusion of carbon into stainless steel. Several mils of copper or chromium plated on Type 316 stainless steel retard diffusion of carbon into the stainless steel for extended service up to about $1650 \mathrm{~F}$. 

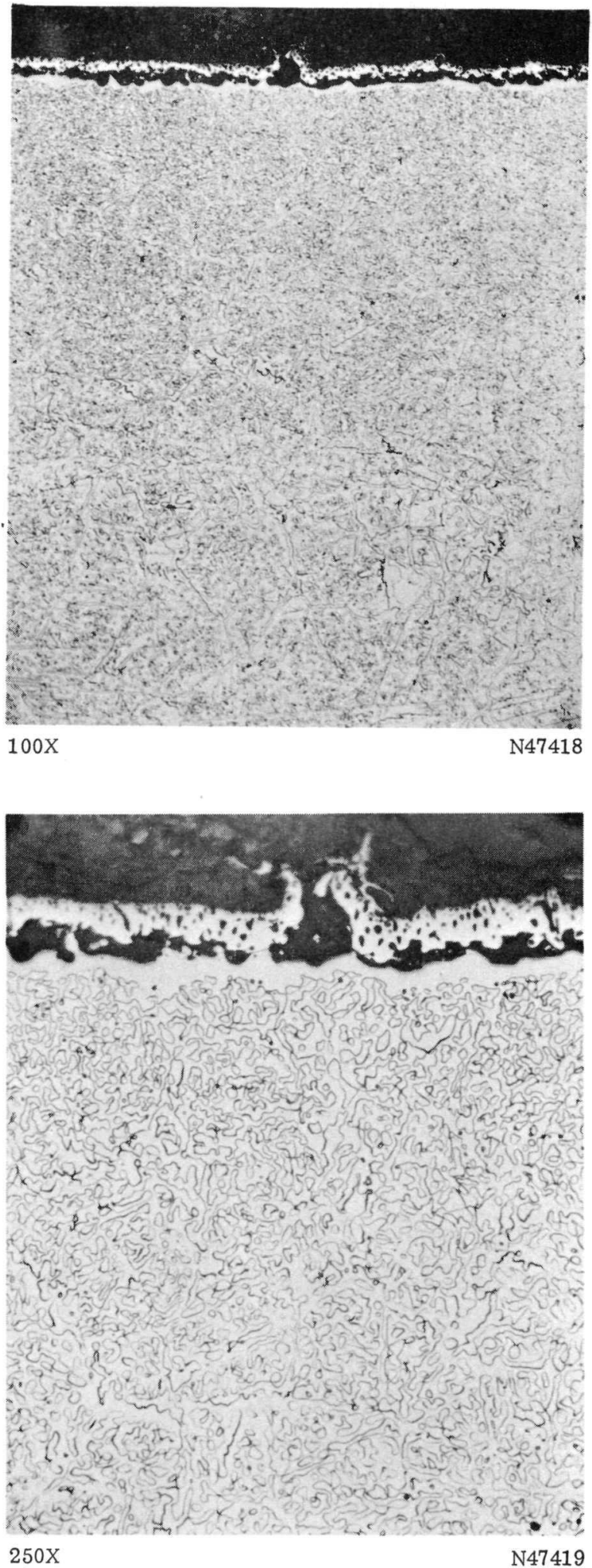

FIGURE 12. INTERFACE OF GRAPHITE WITH TYPE 316 STAINLESS STEEL AFTER REACTION AT $1850 \mathrm{~F}$ FOR 1000 HR Etchant: 4 parts hydrochloric acid and 1 part nitric acid. 

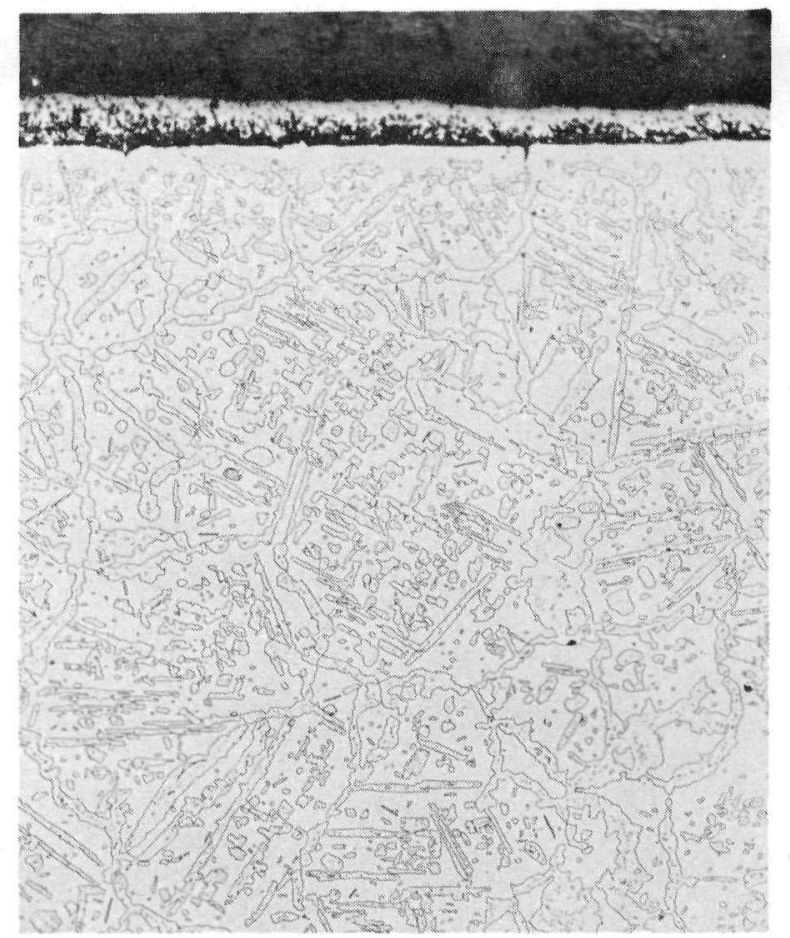

$100 \mathrm{X}$

N47434

a. 1.5-Mil Copper Plate

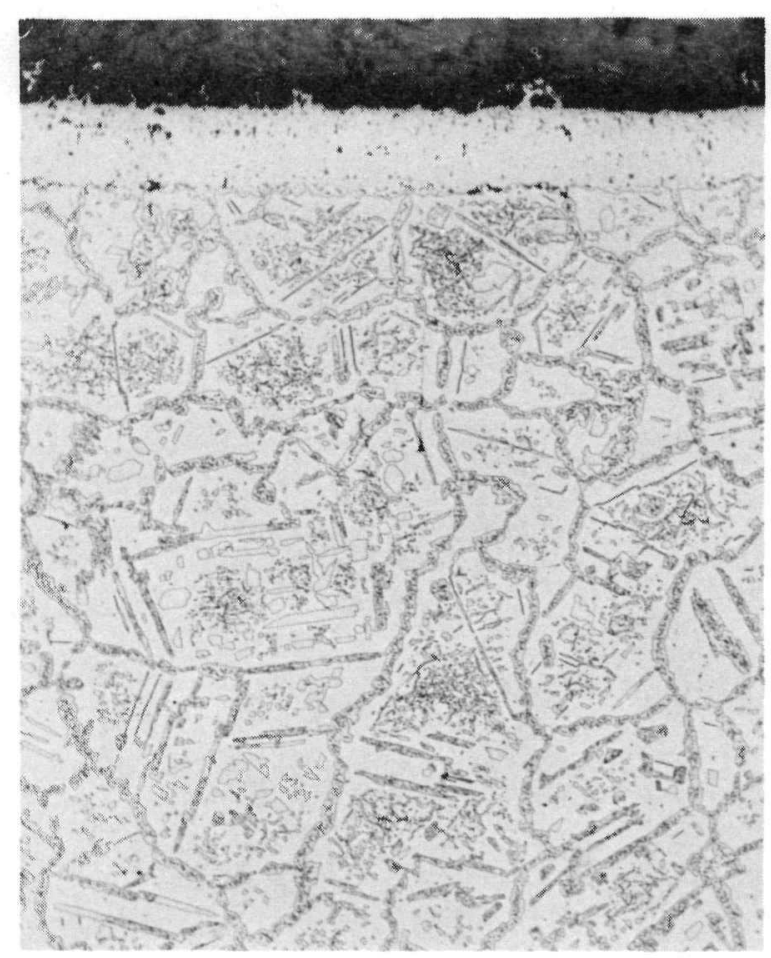

$100 \mathrm{X}$

N47445

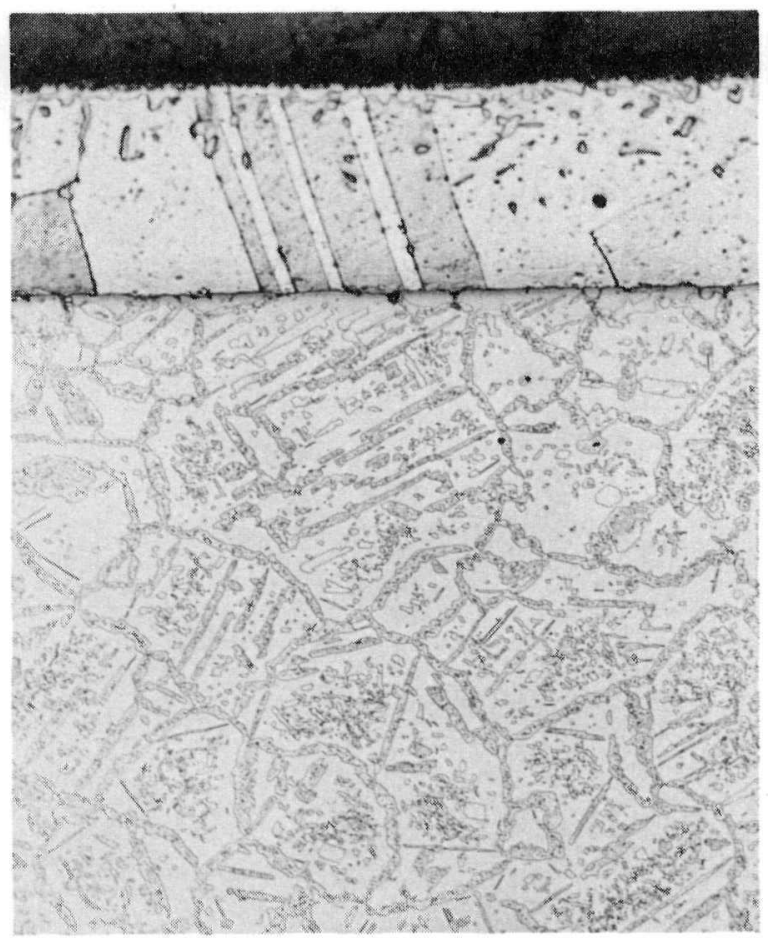

$100 \mathrm{X}$

N47432
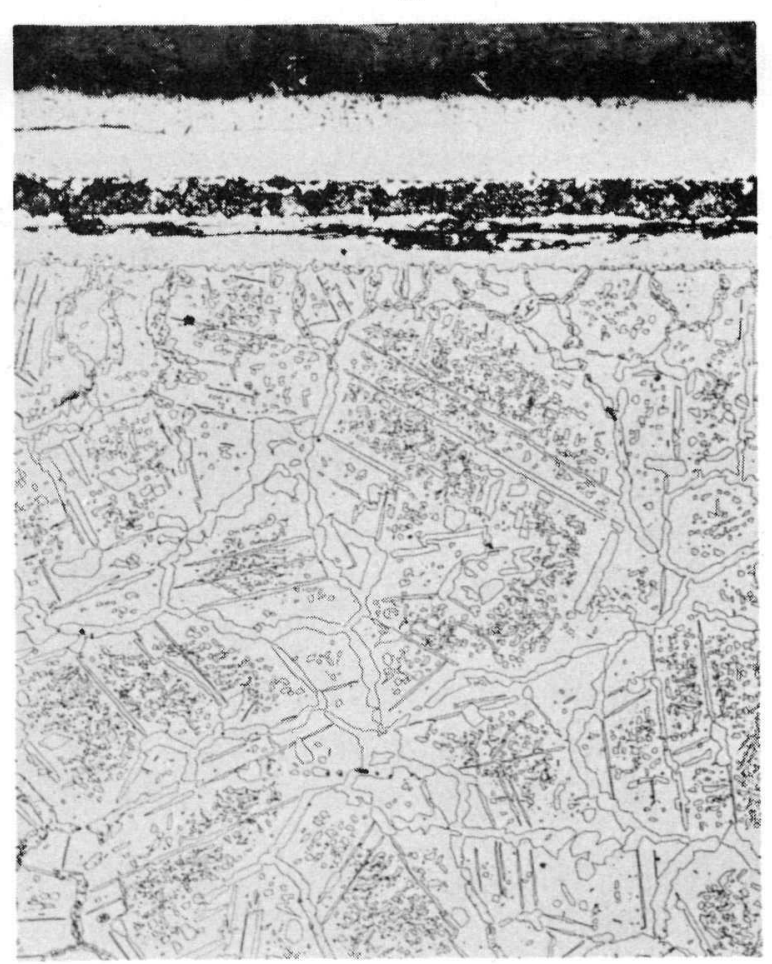

$100 \mathrm{x}$

N47442

c. 2.5-Mil Chromium Plate

d. 6-Mil Chromium Plate

FIGURE 13. INTERFACES OF GRAPHITE WITH COPPER- AND CHROMIUM-PLATED TYPE 316 STAINLESS STEEL AFTER REACTION AT 1850 F FOR 1000 HR

Etchant: 4 parts hydrochloric acid and 1 part nitric acid. 
(4) The effectiveness of Inconel $X$, plated with copper as a barrier to the diffusion of carbon, is limited by interdiffusion of copper with elements from the Inconel $X$. This destroys the usefulness of copper as a barrier at temperatures as low as $1650 \mathrm{~F}$.

\section{REFERENCES}

(1) Metals Handbook, American Society for Metals (1948), pp 1181-1183.

(2) Schwarzkopf, P., and Kieffer, K., Refractory Hard Metals, The Macmillan Company, New York (1953), pp 122-137.

(3) Grosvenor, A. W., Editor, Basic Metallurgy, American Society for Metals (1954), pp 413-433.

(4) Fulkerson, S. D., and Lambert, F. J。, "Carbon Penetration Into Stainless Steel at Elevated Temperature and in Vacuum", Y-2 (October 17, 1947).

(5) Giacobbe, J. B., "Mechanism of Carburization of Some Stainless Steels", Transactions of the American Society for Metals, 45, pp 134-150 (1953).

AFG:MWM/njp:bwl 